\title{
SCHOOL DESEGREGATION: LEGAL REALISM, REASONED ELABORATION, AND SOCIAL SCIENCE RESEARCH IN THE SUPREME COURT
}

\author{
MARK G. YUDOF* \\ The commands of the Constitution cannot fluctuate with the shifting tides \\ of scientific opinion. \\ - Chief Justice Warren Burger ${ }^{1}$ \\ Old subterfuges, once exposed, can almost never gain credibility. \\ - Professor Guido Calabresi ${ }^{2}$ \\ I

\section{INTRODUCTION}

A few years ago Professor Harvie Wilkinson wrote that Brown $v$. Board of Education ${ }^{3}$ evoked a "certain nostalgia" for him, for Brown was "one of those last, great actions whose moral logic seemed so uncomplex and irrefutable, and whose opposition seemed so thoroughly extreme, rooted as it was in notions of racial hegemony and the constitutional premises of John C. Calhoun." "This is a nostalgia that I share. Brown was premised on the notion that state statutes and constitutions that require the separation of white and black children in the public schools are designed to and have the effect of stigmatizing black Americans as inferior beings. In the words of Charles Black, "the social meaning of segregation is the putting of the Negro in a position of walled-off inferiority ... [and] such treatment is hurtful to human beings. ${ }^{5}$ Whatever the original understanding of the fourteenth amendment, ${ }^{6}$

\footnotetext{
* John S. Reddit Professor of Law, University of Texas at Austin.

1. Eisenstadt v. Baird, 405 U.S. 438, 470 (1972) (Burger, C.J., dissenting). But see Ballew v. Georgia, 435 U.S. 223, 231 n.10 (1978) (Blackmun, J.), "We . . note that the Chief Justice did not shrink from the use of empirical data in Williams $v$. Florida, 399 U.S. 78, 100-02, 105 (1970), when the data were used to support the constitutionality of the six-person criminal jury, or in Colgrove v. Battin, 413 U.S. 149, $158-60$ (1973). ..."

2. Calabresi, The Problem of Malpractice: Trying to Round Out the Circle, 27 U. TononTo L.J. 131, $140(1977)$.

3. 347 U.S. 483 (1954).

4. J. H. Wilkinson, Serving Justice 133 (1974) [hereinafter cited as Wilkinson].

5. Black, The Lawfulness of the Segregation Decisions, 69 YALE L.J. 421,427 (1960). See generally C. Vann Woodward, The Strange Career of Jim Crow (3d ed. 1974); see also Brest, The Supreme Court, 1975 Term-Foreword: In Defense of the Antidiscrimination Principle, 90 HaRv L. REv. 1, 8-12 (1976); Cahn, Jurisprudence, 30 N.Y.U. L. REv. 150, 158-59 (1955).

6. See, R. Berger, Government by Judiciary (1977); P. Brest, Processes of Constitutional Decisionmaking 463-76 (1975); Bickel, The Original Understanding and the Segregation Decision, 69 Harv. L. Rev. 1 (1955); Frank \& Munro, The Original Understanding of Equal Protection of the Laws,
} 
the antidiscrimination principle, embodying the ethical assertion that racedependent government decisions should be disfavored, is a principle of wide moral appeal that properly informs the interpretation and application of the Equal Protection Clause of that amendment.

But things are not as simple as they were in the early years after Brown. Articulating constitutional entitlements and devising remedies to protect them are very different matters. If the wrong is discrimination by race, the most natural remedy is to require nondiscrimination. ${ }^{7}$ But, as history demonstrates, government authorities may be recalcitrant in implementing a nondiscrimination regime. ${ }^{8}$ For this and other reasons, what constitutes good faith implementation of a desegregation decree may be difficult to discern. Reliance comes to be placed on more easily administrable per se rules, and the distinction between nondiscrimination and racial dispersion becomes blurred. ${ }^{9}$ This is compounded by the fact that racial discrimination may be less visible as pupil assignment becomes a matter for official discretion and as neutral justifications are put forward for policies that perpetuate school segregation:

It is quite easy for the Constitution to void a state law or regulation that requires, to take an extreme example, policemen to give speeding tickets only to black drivers. It is inestimably more difficult for it to deal with an individual policeman who pulls mostly blacks to the side of the road. "Those I stopped were speeding," the policeman will inevitably say. Invariably, such invisible' discrimination has some neutral nonracial justification. The policeman stops only speeders; the employer who hires only whites is seeking the bestqualified man; the restaurateur of a largely white establishment serves only those in coats and ties; the school board chairman of a predominantly segregated school district is seeking to preserve the values of neighborhood schools. But it is always very hard to tell in any given situation what in fact is afootthe neutral justification or 'invisible' race discrimination. ${ }^{10}$

1972 WASH. U. L.Q. 421 ; Karst, The Supreme Court, 1976 Term-Foreword: Equal Citizenship Under the Fourteenth Amendment, 91 HARV L. REv. I, 11-21 (1977).

7. See generally L. Graglia, Disaster by DeCree (1976); Yudof, Equal Educational Opportunity and the Courts, 51 Tex. L. Rev, 411, 447-48 (1973) [hereinafter cited as Equal Educational Opportunity].

8. See generally H. Horowitz \& K. Karst, Law, Lawyers, and Social Change 239-40 (1969); D. Kirp \& M. Yudof, Educational Policy and the Law 307-18 (1974); B. Muse, Ten Years of Prelude: The Story of Integration Since the Supreme Court's 1954 Decision (1964); Bickel, The Decade of School Desegregation: Progress and Prospects, 64 Colum. L. Rev. 193 (1964); Fleischer, Study of Circumvention: The Enforceability of "Brown," 41 DEN. L.J. 165 (1964); Meador, The Constitution and the Assignment of Pupils to Public Schools, 45 VA. L. Rev. 517 (1969): Powe, The Road to Swann: Mobile County Crawls to the Bus, 51 TEx. L. Rev. 505 (1973); Note, Effect of School Assignment Laws on Federal Adjudication of Integration Controversies, 57 Colum. L. Rev. 537 (1957).

9. See L. Graglia, supra note 7, at 52-58; Dunn, Title VI, The Guidelines E School Desegregation in the South, 53 VA. L. REv. 42 (1967); Recent cases, Equal Protection of the Laws: The H.E.W. Guidelines are Minimum Standards for a Free Choice School Desegregation Program, 81 HARV. L. REV. 474 (1967); Comment, The Courts, HEW, and Southern School Desegregation, 77 YALE L..J. 321 (1967).

10. Wilkinson, supra note 4, at 133-34. See generally Simon, Racially Prejudiced Governmental ACtions: A Motivation Theory of the Constitutional Ban Against Racial Discrimination, 15 SAN Diego L. REv. 1041 (1978). 
This almost inevitably leads to consideration of discriminatory motives, of nonstigmatic injury to racial minorities, and of the substantiality of the neutral justifications. " "[T]reacherous problems of legal proof" are involved. ${ }^{12}$ And whatever the resolution of particular litigations, the framework for decisionmaking is a far cry from the simple moral imperative of Brown.

These changes in the character of school desegregation litigation are reflected in a dissensus among the strongest proponents of Brown as they divide over the questions of what constitutes intentional racial discrimination and what is the appropriate remedy for such discrimination. This tends to be reflected in the debates over busing to achieve racial balance, as some see this as the logical remedy for state-fostered segregation ${ }^{13}$ and others perceive that the remedy itself is a violation of the antidiscrimination principle. ${ }^{14}$ More pragmatic groups and individuals reject either extreme in favor of a calculus that takes into account the social, political, and economic costs of racial dispersion ("integrationist") remedies. ${ }^{15}$ Still others seek to substitute for the entitlement to nondiscriminatory treatment an entitlement to a process free of significant racial prejudice $^{16}$ or to a particular outcome, ${ }^{17}$ such as an integrated education.

11. See generally Brest, Palmer v. Thompson: An Approach to the Problem of Unconstitutional Legislative Motive, 197 I SUP. CT. REv. 95; Eisenberg, Disproportionate Impact and Illicit Motive: Theories of Constitutional Adjudication, 52 N.Y.U. L. REv. 36 (1977); Ely, Legislative and Administrative Motivation in Constitutional Law, 79 YAle L.J. 1205 (1970); Fiss, Racial Imbalance in the Public Schools: The Constitutional Concepts, 78 HARv. L. REv. 564 (1965); Perry, Disproportionate Impact Theory of Racial Discrimination, 125 U. PA. L. REv. 540 (1977); Simon, supra note 10; Note, Foreseeable Racial Segregation-A Presumption of Unconstitutionality, 55 NEB. L. REv. 144 (1975); Note, Reading the Mind of the School Board: Segregative Intent and the De Facto/De Jure Distinction, 86 YALE L.J. 317 (1976).

12. Wilkinson, supra note 4, at 134. See generally Simon, supra note 10; Note, Reading the Mind of the School Board: Segregative Intent and the De Facto/De Jure Distinction, supra note 11.

13. See, e.g., G. Orfield, Must We Bus? Segregated Schools and National Policy (1978); U.S. Comm'n on Civil Rights, Twenty Years After Brown: Equality of Educational OpPORTUNITY (1975); Dimond, School Segregation in the North: There is But One Constitution, 7 Harv. C. R.-C. L. L. REv. 1 (1972); Hawley and Rist, On the Future Implementation of School Desegregation: Some Considerations, 39 Law \& Contemp. Prob., Spring 1975, at 412-14; Taylor, The Supreme Court and Urban Reality: A Tactical Analysis of Milliken v. Bradley, 21 WAYNE L. Rev. 751 (1975). Compare Fiss, The Charlotte-Mecklenburg Case-Its Significance for Northern School Desegregation, 38 U. CHI. L. Rev. 697 (197I): Goodman, De Facto Segregation: A Constitutional and Empirical Analysis, 60 CAL. L. REv. 275 (1972); Equal Educational Opportunity, supra note 7.

14. See, e.g., Wolf, Courtrooms and Classrooms, in Education, Social Science, and the Judicial Process 97 (R. Rist \& R. Anson eds. 1977); Wolf, Northern School Desegregation and Residential Choice, 1977 Sup. C. Rev. 63; Glazer. Is Busing Necessary? 53 Commentary, Mar. 1972, at 39; L. Graglia, supra note 7.

15. See generally Kirp, Multitudes in the Valley of Indecision: Desegregation in San Francisco's Schools, in Limits of Justice: The Court's Role in School Desegregation 411 (M. Kalodner \& J. Fishman eds. 1978); Kirp, School Desegregation and the Limits of Legalism, 47 PUB. INTEREST 101 (1977); D. Kirp, Why Desegregation Didn't Happen: Race \& Schooling Policy in Oakland (1978) (unpublished work, Grad. School of Public Policy, Univ. of Calif. at Berkeley).

16. See, e.g., Brest, supra note 5; Dworkin, Social Sciences and Constitutional Rights-The Consequences of Uncertainty, in Education, Social Science, and the Judicial Process 20 (R. Rist \& R. Anson eds. 1977); Simon, supra note 10.

17. See generally Fiss, Groups and the Equal Protection Clause, 5 J. Philosophy \& PUB. AfF. 107 (1976); Equal Educational Opportunity, supra note 7. 
The public, however, appears not at all undecided about these issues. While the antidiscrimination principle is now widely accepted, ${ }^{18}$ the public appears to reject remedies overwhelmingly that would move students from their neighborhood schools in order to achieve integration, ${ }^{19}$ whatever their conceptual or legal framework. The much feared "white backlash" of the 1060 s has become the political reality of the $1970 \mathrm{~s}$.

The Supreme Court of the United States has not been immune to these political realities. While it continues to embrace Brown and the nondiscrimination principle, it has begun to clip the wings of integrationist-minded litigants and lower courts. ${ }^{20}$ The movement is often hesitant, there is some vacillation, ${ }^{21}$ and no new majority on school desegregation issues has emerged. Nonetheless there has been a shift in that direction. This has been accomplished largely through the continued refinement of the abstract and vague legal principles that characterized the Court's decisions on race in the late 1960s and early 1970s. ${ }^{22}$ Concepts of intentional discrimination ${ }^{23}$ and of equitable discretion to fashion desegregation remedies ${ }^{24}$ have been rendered more concrete, at least by some of the justices. Specific proof requirements have been substituted for less rigorous ones; the use of presumptions to establish wrongs and determine the extent of remedies has greatly diminished. ${ }^{25}$ As the rules of the game have become more precise and explicit, the antidiscrimination principle has been applied by the Supreme Court in ways that make school integration less inevitable than it appeared only a few years ago.

18. Orfield, supra note 13, at 108-09, 274-78; Taylor, Sheatsley, \& Greely, Attitudes Toward Racial Integration, ScIENTIFIC AM., June 1978, at 42.

19. Thus, despite the acquiescence in and even approval of integration by the public and its elected representatives, if political campaign rhetoric, the success of antibusing bills in Congress, and public opinion surveys are taken as barometers, there is broad opposition to court-ordered busing to integrate the public schools. ORfitend, supra note 13, at 109-18, 233-78.

20. See, e.g., Brennan v. Armstrong, 433 U.S. 672 (1977) (per curiam); School Dist. of Omaha v. United States, 433 U.S. 667 (1977) (per curiam); Dayton Bd. of Educ. v. Brinkman, 433 U.S. 406 (1977); Board of School Comm'rs v. Buckley, 541 F.2d 1211 (7th Cir. 1976), cert. granted, 429 U.S. 1068 (1977); Austin Indep. School Dist. v. United States, 429 U.S. 990 (1976); Pasadena Bd. of Educ. v. Spangler, 427 U.S. 424 (1976); Milliken v. Bradley, 418 U.S. 717 (1974).

21. See Evans v. Buchanan, 555 F.2d 373 (3d Cir.), cert. denied, 434 U.S. 880, reh. denied, 434 U.S. 944 (1977).

22. Compare Green v. County School Bd., 391 U.S. 430 (1968), with Dayton Bd. of Educ. v. Brinkman, 433 U.S. 406 (1977).

23. Compare Keyes v. School Dist. No. 1, 413 U.S. 189 (1973), with Milliken v. Bradley, 418 U.S. 717 (1974)

24. Compare Swann v. Charlotte-Mecklenburg Bd. of Educ., 402 U.S. 1 (1971), with Austin Indep. School Dist. v. United States, 429 U.S. 990, 991 (1977) (Powell, J., concurring). But see Davis v. Board of School Comm'rs, 402 U.S. 33 (1971).

25. Compare Keyes v. School Dist. No. 1, 413 U.S. 189 (1973), with Dayton Bd. of Educ. v. Brinkman, 433 U.S. 406 (1977). Cf. Mount Healthy School Dist. v. Doyle, 429 U.S. 274 (1977) (remanded to district court for further proceedings). 
The social science community also has been influenced by the lack of simple moral logic by which school desegregation questions of the 1970s should be resolved and by growing doubts about integrationist remedies. The near consensus among social scientists at the time of Brown, based upon the most feeble of policy research, that desegregation would work to the advantage of blacks, ${ }^{26}$ has given way to a myriad of more sophisticated and less conclusive research findings. ${ }^{27}$ While I suspect that a majority of social scientists still believe that integration is the appropriate remedy for racial discrimination in school assignments, the attention of political leaders has been riveted on a few studies that tend to support antibusing legislation. ${ }^{28}$ The Coleman Report was widely cited for the propositions that predominantly black schools are not generally underfunded in relation to predominantly white schools, and that socioeconomic integration, rather than racial integration per se, of schools and classrooms holds the greatest hope for improvements in black achievement scores. $^{29}$

26. See generally Appendix to Appellants' Briefs, Brown v. Board of Educ., 347 U.S. 483 (1954), reprinted as The Effects of Segregation and the Consequences of Desegregation: A Social Science Statement, 37 Minn. L. Rev. 427 (1953); Arkes, The Problem of Kenneth Clark, 58 Commentary, Nov. 1974, at 40; Cahn, Jurisprudence, 30 N.Y.U. L. Rev. 150 (1955); Clark, Desegregation Cases: Criticism of the Social Scientist's Role, 5 VILL. L. REv. 224 (1959); Garfinkel, Social Science Evidence and the School Segregation Cases, 21 J. Pol. 37 (1959); Greenberg, Social Scientists Take the Stand: A Review and Appraisal of their Testimony in Litigation, 54 MICH. L. REV. 953 (1956); Gregor, The Law, Social Science and School Segregation: An Assessment, 14 W. REs. L. REv. 621 (1963); Lewis, Parry and Riposte to Gregor's "The Law, Social Science, and School Segregation: An Assessment", 14 W. RES. L. REv. 637 (1963); van den Haag, Social Science Testimony in the Desegregation Cases-A Reply to Professor Kenneth Clark, 6 Vill. L. Rev. 69 (1960).

27. See, e.g., J. Coleman, E. Campbell, C. Hobson, J. McPartland, A. Moody, Weinbeld, \& R. York, Equality of Educational Opportunity (1969) [hereinafter cited as Coleman Report]; C. Jencks, M. Smith, H. Acland, M. Bane, D. Cohen, H. Gintis, B. Heyns, \& S. Michelson, Inequality: A Reassessment of the Effect of Family and Schooling in America (1972) [hereinafter cited as C. Jencks]; N. St. John, School Desegregation; Outcomes for Children (1975); M. Weinberg, Minority Students: A Research Appraisal (1977); Armor, The Evidence on Busing, 28 Pub. Interest 90 (1972); Cohen, The Effects of Desegregation on Race Relations, 39 Law \& Contemp. Prob., Spring 1975, at 271 ; Cohen, Pettigrew, \& Riley, Race and the Outcomes of Schooling, in On Equality of Educational Opportunity 343 (F. Mosteller \& D. Moynihan eds. 1972); Crain \& Mahard, Desegregation and Black Achievement, 42 Law \& Contemp. Prob., Summer 1978, at 17; Epps, The Impact of School Desegregation on Aspirations, Self-Concepts and Other Aspects of Personality, 39 Law \& Contemp. Prob., Spring 1975, at 300; G. Forehand, M. Ragosta, \& D. Rock, Conditions and Processes of Effective School Desegregation (1976); Goodman, supra note 13; Katz. Review of Evidence Relating to Effects of Desegregation on the Intellectual Performance of Negroes, 19 Ам. Psychologist 381 (1964); Levin \& Moise, School Desegregation Litigation in the Seventies and the Use of Social Science Evidence: An Annotated Guide, 39 Law \& ConTemp. Prob., Winter 1975, at 50; Pettigrew, Useem, Normand, \& Smith, Busing: A Review of "The Evidence," 30 Pub. Interest 88 (1973); Rodgers, On Integrating the Public Schools: An Empirical and Legal Assessment, in Racism and Inequality: The Policy Alternatives 125 (H. Rodgers ed. 1975); M. Weinberg, The Relationship Between School Desegregation and Academic Achievement: A Review of the Research, 39 Law \& Contemp. Prob., Spring 1975, at 241; Winkler, Educational Achievement and School Peer Group Composition, 10 J. Human Resources 189 (1975).

28. See generally ORFIELD, supra note 13, 120-21.

29. Coleman RePort, supra note 27. See Orfield, supra note 13, at 121. 
Studies (largely based on the existing literature) conducted by Professor Armor a few years later, found that busing for integration did not close the gap in academic achievement between blacks and whites or decrease racial consciousness among students. ${ }^{30}$ The Armor study appears to have solidified the place of achievement scores as virtually the sole test of whether school integration is worth the candle. According to Professor Orfield, the Armor study significantly reinforced antibusing sentiment in Congress. ${ }^{31}$ Finally, studies of white flight conducted by James Coleman in the mid-1970s supported the notion that court-ordered racial integration was not only worthless, but self-defeating: whites would flee integrated school systems rather than send their children to school with blacks, particularly if the schools were predominantly black. ${ }^{32}$

There were and are, however, many equally distinguished social scientists who question the methodologies and results reached by Armor and Coleman and support different conclusions with their own research. ${ }^{33}$ But the overall result of much of the recent social science research on school integration has been to create a schism between many social scientists and parts of the organized civil rights communities, as the latter perceive that the former are aligned with the antibusing political coalition.

The impact of modern social science research on judges and lawyers is more difficult to pinpoint. Despite the famous reference to social science evidence in Brown, ${ }^{34}$ federal courts frequently appear disinclined to give much credence to social science findings in school desegregation cases. ${ }^{35}$ This is fortunate, considering the vagaries of the research and the disputations over methodology and policy conclusions within the social community. Nonetheless, given the noninterventionist proclivities of the Burger Court, I suspect that the publication and media republication of the analyses of such desegregation critics as Nathan Glazer, ${ }^{36}$ James Coleman, ${ }^{37}$ David Ar-

30. Armor, The Evidence on Busing, supra note 27. Professor Orfield notes that the Armor study focused only on the first year of integration. ORfield, supra note 13 , at 120 .

31. ORFIELD, supra note 13 , at 120.

32. Coleman, Liberty and Equality in School Desegregatioon, 6 Soc. Pol. 9 (1976); J. Coleman, S. Kelly, \& J. Moore, Trends in School Segregation 1968-1973 (1975) [hereinafter cited as Trends in School Segregation]. See Clark, Policy Research and Urban Public Policy, 4 Pol. Analysis 67, 78-79 (1978); Ravitch, The "White Flight" Controversy, 51 Pub. Interest 135 (1978).

33. See articles cited in note 27, supra. See generally R. Crain. The Politics of School DeSEgregation (1968). See also Orfield, White Flight Research: Its Importance, Perplexities, and Possible Policy Implications, in Symposium on School Desegregation and White Flight 43 (1975); Pettigrew \& Green, School Desegregation in Large Cities: A Critique of the Coleman "White Flight" Thesis, 46 Harv. Ed. Rev. I (1976); Robin and Bosco, Coleman's Desegregation Research and Policy Recommendations, 84 SCH. Rev. 352 (1976); Rossell, School Desegregation and White Flight, 90 Pol. SCI. Q. 675 (1976).

34. Brown v. Board of Education, 347 U.S. 483, 494 n.ll (1954).

35. See Equal Educational Opportunity, supra note 7, at 437-45.

36. See, e.g., Glazer, supra note 14, at 41.

37. See, e.g., Coleman, Trends in School Segregation, supra note 32. 
mor, ${ }^{38}$ and Eleanor Wolfe ${ }^{39}$ have indirectly influenced the justices-if only because they are exposed to their ideas in the social and intellectual milieus in which they live and work.

This article explores many of these themes. The following section discusses legal realism, the predicate for a discussion of law and the social sciences. The article then turns to significant school and race cases of the $1970 \mathrm{~s}$ to demonstrate the pragmatic and contradictory ways the Supreme Court has employed social science evidence, and to illuminate a number of problems of doctrine and craftsmanship that the Supreme Court has yet to resolve.

II

\section{An Overview of Legal Realism and its Impact on the Legitimacy of Judicial Review}

Legal historians tell us, perhaps with some exaggeration, that the second half of the nineteenth century was characterized by a formal or mechanical attitude toward the law. ${ }^{40}$ It was during this period that law schools, law reviews, and legal scholarship began in earnest, and these intellectual forces attempted to formulate a coherent jurisprudence. ${ }^{41}$ The law was thought to consist of general rules, fixed for all time, ${ }^{42}$ which were carried to increasingly higher levels of abstraction, with scant attention to factual nuances among cases. The mission of judges was to discover or identify such principles by logical deduction and apply them rigorously. They were not to legislate or create the rules, and the legitimacy of their decisions rested on their expertise in ferreting out the law and in adhering to precedent (stare decisis). ${ }^{43}$ The principles themselves were unified by such overarching conceptual categories as contracts and torts, and law was looked upon as a science akin to chemistry, physics, or biology. As such, the relationship between law and the sciences was limited to asserted methodological similarities; for law itself was a science with its own set of constructs distinct from those of other sciences. Least of all did law need to rely on the nineteenth-century social sciences, a fledgling enterprise at best. There was certainly little explicit reliance on the work of self-

38. See, e.g., Armor, supra note 27 , at 90.

39. See, e.g., Wolf, Northern School Desegregation and Residential Choice, supra note 14.

40. See generally G. Gilmore, The Ages of American Law (1977), The Age of Faith; M. Horowitz, The Transformation of American Law, 1780-1860 (1977); K. Llewellyn, The Common law Tradition: Deciding Appeals $38-41$ (1960) [hereinafter cited as The Common Law Tradition]; E. Purcell, The Crisis of Democratic Theory (1973); M. White, Social Thought in America: The Revolt Against Formalism (1968); White, From Sociological Jurisprudence to Realism: Jurisprudence and Social Change in Early Twentieth-Century America, 58 VA. L. Rev. 999 (1972); White, The Intellectual Origin of Torts in America, 86 YALE L.J. 671, 673-78 (1977).

41. G. GiLmoRE, supra note 40 .

42. Id. at 64 .

43. See generally E. Purcell, supra note 40, ch. 5 (1973); Gilmore, Book Review, 86 Yale L.J. 788 (1977). 
identified social scientists in any formal sense, albeit the law and judges presumably were indirectly influenced by the general intellectual currents of the times.

The twentieth century ushered in many changes that tended to nurture a symbiotic association between law and the social sciences. The social sciences experienced a substantial growth, making its research more accessible and attractive to legal thinkers. The growth of the welfare state and the concomitant emphasis on government intervention increased the points of possible interaction between a growing body of public law and the increasingly respected social sciences. Perhaps the most significant factor was the overthrow of the regime of legal formalism. Under the often abused and misunderstood banner of legal realism, Jerome Frank, Benjamin Cardozo, Karl Llewellyn, and others attacked the basic operating assumptions of the formal model and helped shift attention from "legal" science to social science. ${ }^{\mathbf{4 4}}$

Legal realists were hardly a homogeneous lot adhering to a single party line. Nevertheless, for purposes of illuminating the evolving relation between law and social science a crude and simplistic summary will suffice. Legal realists believed that decisionmaking by judges was a far more subjective and irrational process than earlier generations of scholars had thought. Law reflected social, historical, and economic factors as well as legal precedent and the judge's own value preferences. The judge's task was far from mechanical, as the line between applying identifiable law and fashioning new law was a blurred one. Indeed, there were serious reservations about the ability of the legal system to articulate principles of general application, and much more attention was paid to the facts of individual cases. ${ }^{45}$ In short, law was per-

44. See generally T. Benditt, Law as Rule and Principle (1978); B. Cardozo, The Nature of the Judicial Process (1921); J. Frank, Law and the Modern Mind (1935); J.C. Gray, The Nature and Sources of the Law (2d ed. 1921); A. Hunt, The Sociological Movement in Law (1978); K. Llewellyn, The Bramble Bush: Some Lectures on Law and Its Study (1930) [hereinafter cited as The Bramble Bush]; The Common Law Tradirion, supra note 40; $\mathrm{K}$. Llewellyn, Jurisprudence: Realism in Theory and Practice (1962); E. Patterson, Jurisprudence ch. 18 (1953); R. Pound, Jurisprudence (1959); W. Rumble, American Legal Realism (1968); W. Twining, Karl Llewellyn and the Realist Movement (1973); Casebeer, Escape from Liberalism: Fact and Value in Karl Llewellyn, 1977 DukE L.J. 671 ; D'Amato, The Limits of Legal Realism, 87 Yale L.J. 468 (1978); Dewey, Logical Method and Law, 10 Cornell. L. Rev. 17 (1924); Hart, American Jurisprudence Through English Eyes: The Nightmare and the Noble Dream, 11 GA. L. Rev. 969 (1977): Jackson, The Social Function of Legal Rules, 1976 Ariz. ST. L.J. 525; Linde, Judges, Critics and the Realist Tradition, 82 YALE L.J. 227 (1972); Llewellyn, Some Realism About Realism-Responding to Dean Pound, 44 HARv. L. REv. 1222 (1930); Pound, Mechanical Jurisprudence, 8 Colum. L. Rev. 605 (1908); Taylor, Law and Morality, 43 N.Y.U. L. Rev. 611 (1968); Trubek, Complexity and Contradictions in the Legal Order: Balbus and the Challenge of Critical Social Thought About Law, 11 LAw \& Soc. REV. 529 (1977); White, The Evolution of Reasoned Elaboration: Jurisprudential Criticism and Social Change, 59 VA. L. REv. 279.

45. G. Gilmore, supra note 40, at 88 (referring to the scholarship of Arthur L. Corbin). See generally BendiTT, supra note 44, at 10-11; Llewelly, Some Realism About Realism-Responding to Dean Pound, supra note 44. 
ceived as pluralistic, anticonceptual, and open textured. The "scientific" rules of the past century "were pilloried as nonsensical attempts to portray the life of the law as having been logic rather than experience." 46

The present generation of American lawyers and judges has been largely schooled in the jurisprudential philosophy of legal realism, and this has had significant consequences for law and legal institutions. As any first year law student will attest, there is extreme cynicism about judicial opinions. Judicial opinions are treated as post hoc phenomena, with the "real" reasons for the decision often hidden or obscured by the courts. The standard adage is that what courts and other constituted authorities do is far more important than what they say. ${ }^{47}$ Law is made and not found. ${ }^{48}$ The corollary is that the legal formula articulated in one case does not necessarily limit in any meaningful way the future actions of judges. The formula does no more than resolve the case at hand. The law is what the judges decide it is, and they are relatively unconstrained in the exercise of their decisionmaking power-the only limits being their own preferences and perceptions of the legal process and the role of the courts in the broader political structure. Some modern proponents of legal realism have carried these observations to the point of legal nihilism. ${ }^{49}$

46. Id. at 87. See also Jackson, The Social Function of Legal Rules, 1976 ARIz. ST. L. J. 525.

47. K. Llewellyn. The Bramble Bush, supra note 44, at 89. See also D'Amato, supra note 44, at 469-72.

48. J. Frank, Law and the Modern Mind 50-51 (1963); M. White, supra note 40, at 8.

49. See Bendit, supra note 44, at 10-11: Frank, supra note 48. Stevens, Two Cheers for 1870: The American Law School, in LAw in American History 405, 481 (1971). Consider these comments by Professor Gilmore:

Some of those who followed in Corbin's footsteps carried his teaching to the point of intellectual nihilism. Wesley Sturges ... [of] the Yale Law School ... was one. Early in his career Sturges published a few law review articles which were of an almost unbelievably narrow scope and focus-for example, an elaborate study of the North Carolina case law on the nature of mortgages. . . The point of the study was to demonstrate that the North Carolina law of mortgages made no sense and could most charitably be described as a species of collective insanity on the march. . . The law, as Wesley Sturges conceived it, bore a striking resemblance to the more despairing novels of Franz Kafka. Sturges himself had the courage of his bleak convictions. Ex nihilo nihil. He wrote almost nothing during the remainder of his long career. No one could match Sturges in his penetrating analysis of the most complex legal materials, but he saw no point in playing children's games.

G. Grlmore, supra note 40, at 80-81 (1977). See also Gilmore, supra note 43, at 791: "Corbin, who was not a generalist, was content to leave the theoretical formulations of his predecessors (notably Williston) in ruins without proceeding to a new reconstruction of his own." But see The Common LAw Tradition, supra note 40, at 510-12 ("Sturges' work and writing on arbitration procedure, and the effective running of an arbitration institution, give the lie to any lectures about nonexistence or impossibility of rules.").

Gilmore himself, however, has not emerged untouched by the ravages of legal realism:

When we think of our own or of any other legal system, the beginning of wisdom lies in the recognition that the body of the law, at any time or place, is an unstable mass in precarious equilibrium. . . . But the principal lesson to be drawn from our study [of our legal past] is that the part of wisdom is to keep our theories open-ended, our assumptions tentative, our reactions flexible. We must act, we must decide, we must go this way 
For them there are no general principles; precedent and statutory and constitutional text are irrelevant to the judging process, and there is no principled way to prefer one set of values to any other. Law is essentially irrational. ${ }^{50}$

One result of legal realism, either in its most virulent or more modest forms, is to question the legitimacy of the legal system. If judges are not experts in finding established law, but are called upon to fashion law, why should not the task be assigned to democratically elected legislative bodies? If all legal judgments are subjective, bordering on the irrational, how is one result to be preferred to another? ${ }^{51}$

or that. Like the blind men dealing with the elephant, we must erect hypotheses on the basis of inadequate evidence. That does no harm-at all events it is the human condition from which we will not escape-so long as we do not delude ourselves into thinking that we have finally seen our elephant whole.

G. Gilmore, supra note 40, at 110 (1977). Perhaps hope lies in Gilmore's perception that there is an elephant. Llewellyn notes the ancient proverb, "It is easy to paint a goblin. It is hard to paint a horse." The Common Law Tradition, supra note 40, at 511 , n.4a.

50. Professor Graglia embraces the nihilist variant of legal realism. Consider these provocative passages from L. GraGlia, supra note 7, at 19-20 (1976):

Principles make law and life manageable, but our principles, like the interests they serve, are many and often conflicting - or there would be no difficulty in reaching decisions and, indeed, little to decide. A principle's capacity to determine the future is, therefore, limited. The meaning of a decision or opinion is not an existent entity to be discovered, like a vein of gold, by diligent search; it must, within limits, be supplied by later decision makers.

Most important, the Supreme Court, in deciding that a challenged governmental action is unconstitutional, is usually faced with an essentially impossible task. . . The fact is ... that the provisions of the Constitution-for example, the provisions of the Fourteenth Amendment ... offer little or no guidance to resolution of most of the problems actually brought to the Court. . . To a large extent ... one who looks in the court's opinions for an explanation and justification of the Court's decisions invalidating government action [in terms of the logical implications of Constitutional provisions] is looking for what cannot be found. Finally, the legal ideal of continuity and stability impels judges to accommodate their decisions to the formulations of prior ones, even with some loss of clarity and candor. Maintaining the appearance of continuity has value, but the cost in rationality and realism can be high.

But see id. at 30: "A decision is adequately justified if it is or: can be based on a principle whose validity and applicability few will openly or persuasively challenge." Llewellyn, in his later work, describes nihilists such as Graglia as "misguided souls." The Common Law Tradition, supra note 40 , at 510 .

51. As early as 1927, Morris Cohen perceived the dilemma:

'To be ruled by a judge,' [Morris Cohen] declared, 'is, to the extent that he is not bound by law, tyranny or despotism.' When the realists said that every judge's decisions were necessarily subjective, and that those decisions were the only law, Cohen charged. they were justifying judicial despotism and political authoritarianism.

[T] he realists' movement could not explain away the intellectual problems they generated. First, how could the idea of the subjectivity of judicial decision be squared with the doctrine that free men should be subject only to known and established law ... ? Second, if the acts of government officials were the only real law, on what basis could anyone evaluate or criticize those acts? What, in other words, was the moral basis of the legal system in particular and of democratic government in general?

E. Purcell, supra note 40, at 91, 94 [quoting Cohen, Positivism and the Limits of Idealism in the Law, 
The crisis of legitimacy was particularly severe for constitutional review by federal courts in view of the continuous debate over the historical basis for and wisdom of such judicial review. The legal realists challenged the very essence of the constitutional tradition-the assumption that judicial review, however undemocratic, was constrained by constitutional text, history, and precedent. ${ }^{52}$ Only the raw, unfettered exercise of powers by unelected judges remained. ${ }^{53}$

It is not my purpose to engage in a critical analysis of the shortcomings and strengths of the legal realist position. ${ }^{54}$ Rather, my point is that it is impossible to understand Brown and its progeny, and the controversies to which desegregation cases have given rise without taking into account the challenge presented by the legal realists. The challenge was met in many ways, ${ }^{55}$ with

27 Colum. L. Rev. 237, 244 (1927)]. See also, L. Fuller, The Law in Quest of Itself (1940); Stevens, supra note 49, at 529; Mechem, The Jurisprudence of Despair, 21 IowA L. REv. 669 (1936); White, supra note 44, at 279, 282-83; Hart, supra note 44. But see Casebeer, supra note 44.

52. See generally A. Bickel, The Least Dangerous Branch (1962); C. Black, The People and the Court (1960); A. Cox, The Role of the Supreme Court in American Government (1976); L. Hand, The Spirit of Liberty (3d ed. 1960); L. Lusky, By What Right? (1975); M. Shapiro, freedom of Speech: The Supreme Court and Judicial Review (1966); L. Tribe, American Constitutional Law 9-14, 20-52 (1978); Bishin, Judicial Review in Democratic Theory, 50 S. CAL. L. Rev. 1099 (1977); Freund, Umpiring the Federal System, 54 Colum. L. Rev. 561 (1954); McClesky, Judicial Review in a Democracy: A Dissenting Opinion, 3 Houston L. Rev. 354 (1966).

53. See C. Hughes, The Supreme Court of the United States 120 (1928); J. Frank, supra note 48, at 148 (1930); Hutcheson, The Judgment Intuitive: The Function of the "Hunch" in Judicial Decision, 14 Cornell L. Q. 274 (1929). Compare The Common Law Tradition, supra note 40, at 508 , App. B.

54. The reader may have already sensed that I am sympathetic to the tenets of legal realism, at least in their less radical manifestations.

55. Some insisted that a reasoned elaboration of the basis of a decision was a minimal requirement for legitimacy. See White, supra note 44, and discussion in text. But see Tushnet, Book Review, 22 Amer. J. Leg. Hist. 177 (1978). Others thought that judicial decisions must strive to articulate "neutral principles" to justify particular results. See Wechsler, Toward Neutral Principles of Constitutional Law, 73 Harv. L. Rev. 1 (1959). Professor Black turned to the structures and relationships in the Constitution and among the institutions of government as a supplement to textual exegesis and other methods. See C. Black, Structure and Relationship in ConstituTIONAL LAW (1969). Still others emphasized the capacity of the Supreme Court for moral leadership and education. See Rostow, The Democratic Character of Judicial Review, in Judicial Review And The Supreme Court (L. Levy ed. 1967): Lerner, The Supreme Court as Republican Schoolmaster, 1967 Sup. CT. REv. 127. Professor Dworkin would make "background morality" one of the sources for decisions by judges. See Dworkin, TAKing Rights SERtously (1977). But see Greenawalt, Discretion and Judicial Decision: The Elusive Quest for the Fetters that Bind Judges, 75 Colum. L. Rev. 359 (1975). For a variety of other approaches to the quandaries of legal realism, see, e.g., J. Noonan, Persons and Masks of the Law: Cardozo, Holmes, Jefferson and Wythe as Makers of The Masks (1976); M. McDougal \& Associates, Studies in World Public Order (1960); Casebeer, supra note 44, at 671; Chayes, The Role of the Judge in Public Law Litigation, 89 Harv. L. Rev. 1281 (1976); Dahl, Decision-Making in a Democracy: The Supreme Court as a National Policy-Maker, 6 J. PuB. L. 279 (1957); Deutsch, Neutrality, Legitimacy, and the Supreme Court: Some Intersections Between Law and Political Science, 20 STAN. L. REv. 169 (1968); Linde, Due Process of Lawmaking, 55 NEB. L. REv. 197 (1976); Tribe, The Emerging Reconnection of Individual Rights and Institutional Design: Federalism, Bureaucracy, and Due Process of Lawmaking, 10 
varying degrees of success. For present purposes I wish to emphasize two specific types of responses. First, some legal realists attempted to forge a link between law and the social sciences, as will be discussed in the next section of this article. Second, a jurisprudential school of "reasoned elaboration" blossomed in the post-World War II period, which attempted to establish the legitimacy of judicial review by resorting to the notion that judicial opinions should be thorough, clear, internally consistent, and candid in exploring the general principles, neutrally applied, that guide decisions. ${ }^{56}$ Section IV of this article returns to this theme, examining the Supreme Court's recent school desegregation decisions.

\section{III}

\section{Law and the Social Sciences}

If law itself was not a science, perhaps salvation would lie with those who had a higher claim to rationality, objectivity, and scientific method. ${ }^{57}$ If all else fails, institutions such as courts may justify the exercise of their powers by reference to a simple proposition: the outcomes of their decisions, however questionable the processes, are beneficial to society. Benefit may be demonstrated by some general consensus that court decisions have bettered American life, or by a social science calculus that demonstrates some maximization of satisfaction or utility in terms of some widely shared policy objec-

Creighton L. Rev. 433 (1977). Many of these responses to the crisis of legal realism appear to seek solutions to the problems of ethical relativism in the false prophet of process-due process, judicial process, or processes of decisionmaking. In this sense, they appear to parallel the philosophical trend toward grounding a theory of rights in contractarian garb. See, e.g., R. Nozick, Anarchy, State and Utopia (1974); J. Rawls, A Theory of Justice (1971); J. Buchanan, THE Limits OF LiBERTY (1975).

56. See generally Wechsler, supra note 55. White, supra note 44. But see Tushnet, supra note 55 .

57. See generally A. Davis, The United States Supreme Court and the Uses of Social Science Data (1973); Law and Sociology: Exploratory Essays (W. Evan ed. 1962); L. Friedman \& S. Macaulay, Law and the Behavioral Sciences (1969); D. Horowitz, The Courts and Social Policy (1977); Education, Social Science, and the Judicial Process, (R. Rist \& R. Anson eds. (1977); P. Rosen, The Supreme Court, and Social Science (1972); E. Schur, Law and Society (1969); C. Weiss, Using Social Research in Public Policy Making (1977). Allen, Criminal Justice, Legal Values and the Rehabrilitation Ideal, 50 J. CRIM. L. 226 (1959); Baade, Hoggan's History-A West German Case Study in the Judicial Evaluation of History, 16 Aм. J. CoмP. L. 391 (1968); Baade, Social Science Evidence and the Federal Constitutional Court of West Germany, $23 \mathrm{~J}$. PoL. 421 (1961); Hazard, Limitations on the Uses of Behavioral Science in the Law, 19 CASE W. ReS. L. REv. 71 (1967); Karst, Legislative Facts in Constitutional Litigation, 1960 SuP. CT. Rev. 75; Korn, Law, Fact and Science in the Courts, 66 Colum. L. Rev. 1980 (1966); Llewellyn, Law and the Social SciencesEspecially Sociology, 62 HARv. L. REV. 1286 (1949); Lochner, Some Limits on the Application of Social Science Research in the Legal Process, 1973 LAw and THE Social Order 815; Miller \& Barron, The Supreme Court, the Adversary System, and the Flow of Information to the Justices: A Preliminary Inquiry, 61 VA. L. REv. 1187 (1975); Robbins, The Admissibility of Social Science Evidence in Person-Oriented Legal Adjudication, 50 IND. L.J. 493 (1975); Symposium, The Courts, Social Science, and School Desegregation, 39 Law \& ContemP. Prob., Winter and Spring 1975. 
tives. ${ }^{58}$ "The slogan 'law is a science' [becomes] 'law is a social science." "59 Economics, political science, psychology and sociology do not so much inform and facilitate legal decisions as they are "in some sense part and parcel of the law." 60 In the process, much confusion was generated between the "facts" of what the law is and normative judgments about what the law should be. ${ }^{61} \mathrm{~A}$ few brave souls even toyed with the notion that ethical statements are empirically verifiable. ${ }^{62}$

With this link forged between social science and twentieth century jurisprudence, however confused, it is not surprising that the Supreme Court relied on social science evidence to justify its then controversial decision in Brown. Despite Professor Wechsler's early assault on Brown ${ }^{63}$ and Professor Berger's more recent and troublesome venture, ${ }^{64}$ I persist with many others

58. See generally L. TRIBe, supra note 52, at 47-53 (1978); Chayes, The Role of the Judge in Public Law Litigation, supra note 55, at 1281, 1284 (1976).

59. G. Gilmore, supra note 40 , at 87 .

60. Id. Edward Purcell notes a number of developments along these lines:

Because of their concern with the practical operation of the legal process, the realists looked to their colleagues in the social sciences for useful methods and hypotheses. . .

Economics, statistics, and psychology elicited the greatest interest from the legal critics. 'When one approaches the law, not with the idea of formulating its rules into a system, but with an eye to discovering how much it does or can effect...., Llewellyn acknowledged, 'economic theory offers in many respects amazing light.' He called special attention to John R. Commons's institutionalist study, Legal Foundations of Capitalism, as an example. . . When in 1932 Adolph A. Berle, Jr. and Gardiner C. Means published The Modern Corporation and Private Property, a study of the interrelated legal and economic methods of corporate control, they brought to brilliant fruition many of the pleas for such interdisciplinary research.

A large literature on legal psychology grew during the twenties, with behaviorism, Freudianism, and abnormal psychology all playing a role. . . Underhill Moore made the most elaborate attempt to work out a behavioral system for studying and predicting judicial decisions, while other realists attempted to apply the insights of modern psychology to such problems as the rules of evidence. .

[T] hey hoped to make the study of law as objective as possible.

E. Purcell, supra note 40, at 86-87 (footnotes omitted). See also White, supra note 44, at 280-81; Stevens, supra note 49 , at $\mathbf{4 7 0 - 8 1}$.

61. E. Purcell, supra note 40, at 87-94, 172-76. See L. Fuller, The Law in Quest of Itself (1940); White, supra note 44, at 280; Casebeer, supra note 44.

62. See M. White, supra note 40, at 210-15, 244-45. Llewellyn perceived an "immanent natural law" founded upon the mores, life conditions, and prevailing attitudes and practices at a particular time. His approach to values is empirical only in the loosest sense. Law builds upon a sort of anthropology of "the whole stock of practices, standards, [and] ethics that make up the social, economic, and religious phases of society. What is dominant in society, then, is dominant in law." K. Lewellyn, The Bramble Bush, supra note 44, at 117. See also K. Llewellyn, The Common Law Tradition, supra note 44, at 122, 513-14; Llewellyn \& Hoebel, The Cheyenne Way (1941). See generally Casebeer, supra note 44, at 680-81, 696-702; Danzig, A Comment on the Jurisprudence of the Uniform Commercial Code, 27 StAN. L. Rev. 621 (1975).

63. Wechsler, supra note 55. Compare Sandalow, Judicial Protection of Minorities, 75 MICH. L. Rev. 1162 (1977).

64. Berger, supra note 6. 
in thinking that the decision to declare the race discrimination in Brown unconstitutional was about as well justified a constitutional decision as any ever rendered by the Supreme Court. ${ }^{65}$ Ironically, however, the Court could not control its impulse to rely on social science evidence for the proposition that segregated schools were injurious to black children. ${ }^{66}$ Understandably, the Court sought to anticipate and rebut charges of judicial usurpation, subjectivity, and infidelity to the Constitution by grasping for social science straws.

Virtually everyone who has examined the question now agrees that the Court erred. The proffered evidence was methodologically unsound. The damage of the dual school system, the systematic treatment of blacks as inferior beings, is a historical and not an empirical truth. The Court itself never allowed the "factual" questions decided in Brown to be reopened. ${ }^{67}$ And the Court made few points in assuaging concerns rooted in legal realism:

Judicial recital of "realistic" premises may thus be more hindrance than help in explaining and justifying a constitutional ruling intended for general and varying application, whether the premise is diagnostic, as in school desegregation, or instrumentalist, as in criminal procedure. ... [I]t is misleading to justify general constitutional rules or principles by the Supreme Court's perception of facts, when the presence or absence of such supposedly decisive facts is not thereafter open to examination by either lower courts or lawmakers - as the psychological and social consequences of segregation ... were not. Such "factual" justification of per se rules in constitutional law is a far cry from the realism of a Brandeis brief supporting the judgments of legislators against charges of irrationality. . . ${ }^{68}$

It is difficult to make systematic observations about the reliance of courts on social science research; the uses to which the evidence is put depend, in part, on its nature. Since Brown, my impression is that, with few notable exceptions, there has been a marked decline in the willingness of the Supreme Court to embrace social science evidence as the basis for constitutional decisions. To be sure, the Court occasionally makes reference to social science research, but primarily on factual matters: ${ }^{69}$ What is the black population of

65. See, e.g., L. Graglia, supra note 7 .

66. Brown v. Board of Educ., 347 U.S. $483,494 \mathrm{n} .11$ and accompanying text.

67. Equal Educational Opportunity, supra note 7 , at 439-45.

68. Linde, supra note 44 , at 242 .

69. See Ingraham v. Wright, 430 U.S. $651,660,681-82$ (1977):

Despite the general abandonment of corporal punishment as a means of punishing criminal of fenders, the practice continues to play a role in the public education of schoolchildren in most parts of the country. Professional and public opinion is sharply divided on the practice. ...

Assessment of the need for, and the appropriate means of maintaining, school discipline is committed generally to the discretion of school authorities subject to state law.

Compare id. at $68 \mathrm{l}-82, \mathrm{n} .53$.

The seriousness of the disciplinary problems in the nation's public schools has been documented in a recent congressional report. Senate Committee on the Judiciary, Subcommittee to Investigate Juvenile Delinquency, Challenge for the Third Century: Educa- 
a school district? Who stands to benefit or lose from a particular law? But even with regard to matters of causation, the crisis of legal realism has not abated, and pragmatic judges, pressed to make decisions that would confound the prophets, occasionally resort to whatever justifications are at hand. A profound skepticism has crept into the relationship between law and the social sciences, a skepticism I share. For every judge who relies on policy research, there is another (or occasionally the same judge in a different case) who decries reliance on the vagaries of social science research in constitutional adjudications.

The source of the law's newfound sense of independence from the social sciences lies not in the repudiation of legal realism, but in the realization that the social sciences are also suffering from a crisis of legitimacy, one that perhaps runs deeper than that in the law. There are widespread doubts in the scientific, legal and political communities as to the objectivity, ${ }^{\mathbf{7 0}}$ maturity, ${ }^{71}$ and relevance of the social sciences to the constitutional decisions rendered by courts. ${ }^{72}$ This is in part attributable to what are perceived as the failures of social science-based policy strategies during the War on Poverty of the 1960s. It is also a function of the dissensus in the social sciences themselves, doubts about the utility of survey research, and the growing feeling that there are enormous gaps in our knowledge that make reliance on social science research

tion in a Safe Environment-Final Report on the Nature and Prevention of School Violence and Vandalism, 95th Cong., 1st Sess. (Comm. Print 1977).

Thus the court declined to review the social science research on the efficacy of corporal punishment in preventing student misbehavior, while relying on a social science study to demonstrate the seriousness of disciplinary problems in public schools. Perhaps its treatment of research can be justified, since the magnitude of violence is a factual question, while the question of deterrence involves consideration of causal relationships.

70. See generally Controversies and Decisions (C. Frankel, ed., 1976); A. Gouldner, The Coming Crisis of Western Sociology (1970); T. Kuhn, The Structure of Scientific Revolutions (2d ed. 1970); M. Polanyi, Personal Knowledge 47 (1958); K. Popper, Objective KNowledge: An Evolutionary Approach (1972); Gouldner, Anti-Minotaur: The Myth of a ValueFree Sociology, 9 Soc. Рrob. 199 (1962); Homans, What Kind of Myth is the Myth of a Value-Free Social Science?, 58 Soc. ScI. Q. (1978); Levin, Education, Life Chances, and the Courts: The Role of Social Evidence, 39 Law \& Contemp. Prob., Spring 1975, at 217.

71. See, e.g. Cohen and Weiss, Social Science and Social Policy: Schools and Race, in Education, Social Science, and the Judicial Process 72 (R. Rist \& R. Anson eds. 1977) [hereinafter cited as Social Science and Social Policy]; Sapir, The Contribution of Psychiatry to an Understanding of Human Behavior, 42 Aм. J. Soc. 862, 865-66 (1937).

72. See, e.g., Black, The Lawfulness of the Segregation Decisions, 69 YALE L.J. 421 (1960); Cahn, supra note 26; Social Science and Social Policy, supra note 71; Coons, Recent Trends in Science Fiction: Serrano Among the People of Number, in Education, Social Science, and The Judicial ProCEss 50 (R. Rist \& R. Anson eds. 1977); Clark, Social Science, Constitutional Rights, and the Courts, in Education, Social Science, and the Judicial Process 1 (R. Rist \& R. Anson eds. 1977); Dworkin, supra note 16; Wisdom, Random Remarks on the Role of the Social Sciences in the Judicial Decision-Making Process in School Desegregation Cases, 39 Law \& Contemp. Prob., Winter 1975, at 134, 138; Equal Educational Opportunity, supra note 7. But see Clark, The Desegregation Cases: Criticism of the Social Scientist's Role, supra note 26; Rosen, Social Science and Judicial Policy Making, in Using Social Research in Public Policy Making, supra note 57, at 109, $111-15$. 
in complex policy areas doubtful. ${ }^{73}$

The core difficulty in employing the social sciences in the realm of complex policy decisionmaking is the "divergent and pluralistic character of social policy research."74 The social sciences, for all the advances they have made, are in many ways pre-sciences. Greater knowledge and more sophisticated research techniques do not yet lead to a convergence on particular paradigms as in the physical sciences; ${ }^{75}$ rather, they lead at best to complexity and the promulgation of conflicting paradigms. ${ }^{76}$ At worst, the number of observations of social phenomena are increased without any accompanying theory to explain causal relationships. ${ }^{77}$ Correlations are no substitute for a sound epistemology. Consider Professor Dworkin's admonition on the use of social science correlations by courts:

When judgments rest simply on correlations between observed phenomena, there is necessarily an element of arbitrariness introduced by the choice of categories whose correlation is taken to be significant. . . The choice here is not restricted, as it is in physical science, by the requirements of a dominant mechanical model, or by the requirement to provide a substitute for the dominant model. That is a substantial difference between social science and the physical sciences that we must always bear in mind. It has a further consequence. When you lack a mechanical model, and you make judgments simply on coprelations between observed phenomena, the kinds of techniques necessary to provide arguments for and against the hypothesis belong entirely to a very arcane subject, namely, statistics. The mathematical concepts of statistics are much more removed from the ordinary vocabulary of

73. See Social Science and Social Policy, supra note 71.

74. Id. at 91 .

75. Id. at 74

76. [F]or the most part, the improvement of research on social policy does not lead to greater clarity about what to think or do. Instead. it usually tends to produce a greater sense of complexity. The result is endemic to the research process. For what researchers understand by improvement in their craft leads not to greater consensus about research problems, methods, and interpretation of results, but to more variety in the ways problems are seen, more divergence in the ways studies are carried out, and more controversy in the ways results are interpreted. $I d$. at 73 .

A physicist friend of mine once commented that Einstein's theory of relativity advanced the hard sciences by reducing the millions of observed mysteries in the physical world to a few basic mysteries which scientists have not yet been able to explain. Social science research, on the other hand, expands the number of mysteries and has not yet achieved the breakthrough that would enable social scientists to explain new observations in terms of a limited number of basic principles. Thus, there is a paradox in modern social science. The more knowledge gained, the more apparent our ignorance. Often there is an inverse relationship between higher levels of sophistication in research and the utility of the results of that research for policymakers. Some dispute whether such a "breakthrough" is possible, arguing that the central concepts of social science and natural science are incompatible. See P. W'inch, The Idea of a Social Science and its Relation тo Philosophy 94 (1958).

77. Social Science and Social Policy, supra note 71. This also suggests that many social science studies may not be comparable and that findings are not cumulative. "Under such conditions, scientific improvement is a term with a somewhat special-and often purely technical-meaning. The fruit of such scientific developments is sometimes rich and always varied, but not necessarily very coherent." Id. 
a trial judge than are the concepts of physics or chemistry that he might encounter in, for example, a complicated patent case. This accounts, I think, to a large degree, for the sense of distance and dependence a judge has when asked to consider complex causal hypotheses in social science. There is one further point. Correlations of social phenomena are fragile in the sense that the data, the behavior that forms the correlation, can change very quickly. Furthermore, the fact of an hypothesis--the fact that a correlation has been made-can affect this change. This is what is called the Heisenberg effect. ${ }^{78}$

The cumulative result of these stresses is a new realism about the social sciences very much akin to the legal realism that so formidably attacked the premises of formalism. As a case in point, desegregation research is characterized by dissensus, inconclusiveness, indeterminacy and subjectivity. Propositions are not only debated in books and scholarly journals, but in the newspapers, at press conferences, and over the air waves. ${ }^{79}$ Social science research involves not only investigation and inquiry, but the conscious effort to influence policy. ${ }^{80}$ Under such circumstances, the claims of social science to legitimacy are no more compelling than the claims of law. The New Jerusalem is a distant mirage for both.

In the light of the shortcomings of modern social science, it would be convenient, both for jurists and for legal scholarship, if the ties between law and social science could be completely severed. Symmetry and simplicity are almost invariably attractive. But, alas, to borrow from the legal realists, the life of the law does not lie in symmetry or simplicity. The law reflects the complexities of social life and its endless asymmetrics, and the social sciences are dedicated to unraveling the many mysteries of human behavior and interaction. To the extent that social science research tells us what people and their institutions are like, yielding facts about the real world, ${ }^{81}$ it would be absurd

78. Dworkin, supra note 16 , at 23.

79. See, e.g., Scholars in New Rift Over "White Flight", N.Y. Times, June 11, 1978, at 27, col. 1. See generally Clark, Policy Research and Urban Public Policy, 4 PoL'y Analysis 67, 78-79 (1978); Pettigrew and Green, School Desegregation in Large Cities: A Critique of the Coleman "White Flight" Thesis, 46 Harv. Ed. Rev. 1, 2-4 (1976). Compare R. J. Herrnstein, I.Q. in the Meritocracy (1973).

80. Even so staunch a defender of the objectivity of social science research as Charles Frankel admitted this:

There is a sense in which the severest, even the vulgarest, critics of the social sciences may be said to be right. The social sciences . . . are inextricably involved in politics . . . [in] the deliberate, conscious process of competition to influence the ordering of values ....

Frankel, The Autonomy of the Social Sciences, in Controversies and Decisions 9, 29 (C. Frankel ed. 1976).

81. Professor Eleanor P. Wolf notes, however, the difficulties social scientists encounter even in bringing such factual matters to the attention of the courts:

To a social researcher, the use of adversary procedures to secure accurate data about factual matters such as educational resource allocations, or whether school "A" did or did not have space in the winter term of 1969 for 240 children, is absurd. It is like staging a public debate on the subject: What is the population of Washington, D.C.? There are not 
to advocate that the legal system ignore that research. That social science is of limited assistance in unraveling complex causal relationships does not justify disregarding it where the causal connections are less complex or where it establishes factual predicates for value judgments.

Social science research becomes more and more useful as a means of informing legal decisions as the objectives of the legal system are less general, abstract, and aspirational. If a legislature or court seeks answers to such questions as when an automobile driver is so intoxicated as to be a danger to himself and others, what a comparatively safe means of abortion is, and whether pornography breeds antisocial behavior among its viewers, the social sciences, as well as the other sciences, may yield significant insights on the costs, benefits, and wisdom of alternative solutions. If, however, the question is when "life" begins for a fetus, whether homosexual conduct should be made unlawful, or when a person should be deemed so deranged that he or she should not be held legally responsible for the consequences of his or her acts, social science research is much less useful. The concepts of life, sexual morality, and legal responsibility are value laden, abstract, and do not readily lend themselves to instrumental analysis. It would be foolish to believe that scientific method has a significant bearing on the resolution of such questions.

The relevance of social science research to judicial decisionmaking is a function of the sorts of questions that courts ask and how they choose to frame the legal issues. Consider, for example, the exclusionary rule prohibiting convictions on the basis of evidence that has been obtained through official misconduct. ${ }^{82}$ As Justice Linde has argued forcefully, the nature of judicial inquiry differs significantly if the rule is premised on the need to deter police misconduct rather than on the need to vindicate the interests of the criminal defendant in due process of law. ${ }^{83}$ If the question is what process

two sides to purely factual matters of this kind any more than there are two answers to a problem in arithmetic, nor is the answer somewhere in the middle.

Wolf, Courtrooms and Classrooms, in Education, Social Science, and the Judicial Process, supra note 14, at 97, 111-12. See also Rosen, supra note 72, at 109. Wolf is equally adamant about judicial consideration of scientific hypotheses and theories:

A court ruling cannot make a scientific theory impermissible, whether it be the germ theory of disease or any other. ...

"The Sixth Circuit held. . . ." I see Galileo being led away and hear his insistent voice murmuring, according to legend: "And yet-it moves."

Wolf at 118 (citing Monroe v. Board of Comm'rs, 427 F.2d 1005, 1008 (6th Cir. 1970)). Compare P. Winch, supra note 76 , at $9,92-94$.

82. See, e.g., Mapp v. Ohio, 367 U.S. 643 (1961); Miranda v. Arizona, 384 U.S. 436 (1966).

83. The Supreme Court's encounter with unconstitutional practices in law enforcement reveals the problems posed when realism bases constitutional rules on explicit premises of social engineering . . . . The explication of the exclusionary rules became increasingly instrumentalist as the decade wore on, explicitly resting on the need to deter general police misconduct, perhaps because mere principled enforcement of constitutional 
should be afforded criminal defendants, it is a question of fairness and values not easily explicated in social science terms. If the question is what will deter the police from coercing confessions, presumably this is an empirical question that social scientists may study usefully. ${ }^{84}$

Most constitutional rights can be framed in instrumental or noninstrumental ways, thereby giving the courts the power to control the influence of social science evidence. The right to a jury trial may be redefined to include a right to trial by a small group having certain identifiable characteristics; ${ }^{85}$ the prohibition on cruel and unusual punishment may be construed in the light of the deterrent effects of the punishment on criminal misconduct; ${ }^{86}$ the sole purpose of a due process hearing before depriving someone of a property or liberty interest may be to produce fewer erroneous decisions; ${ }^{87}$ and the right to nondiscriminatory treatment by race in the public schools may be perceived as resting on the need to improve the achievement scores, motivation, or psychological well-being of minority youngsters. ${ }^{88}$ While such mutations of constitutional entitlements may provide tempting justifications for courts and allow the social sciences a broader role in constitutional adjudication, almost

\footnotetext{
guarantees directed against the police and invoked by criminal suspects had met with little instinctive assent by public and judges. . . . If instrumentalism of this sort seriously explained the source and rationale of the exclusionary rule, its logic would point toward refinements of the rule so that evidence must be suppressed . . . wherever suppression is thought to deter officers and not where it is not: matching the rule to the reason would produce a constitutional right for some but not for other defendants, depending on whatever empirical generalizations could be found to determine the "effectiveness" of the rule in different kinds of social and institutional settings of police work.

... "A decision of the Supreme Court, if it is based on a factual assumption which is incorrect, may be subject to Congress' power to legislate," said Senator Ervin in defense of Senator McClellan's bill to overturn the Miranda rules on the admissibility of confessions.
}

Linde, supra note 44 , at $240-41$.

84. Judge Jon $O$. Newman cites the major empirical studies of the "effectiveness of the exclusionary rule" in Suing the Lawbreakers: Proposals to Strengthen the Section 1983 Damage Remedy for Law Enforcers' Misconduct, 87 YaLE L.J. 447, 448 n.3 (1978). As one would suspect, he describes those studies as "inconclusive at best" and as falling "far short of establishing that excluding illegally obtained evidence tends systematically to deter misconduct." Id.

85. See Ballew v. Georgia, 435 U.S. 223 (1978).

86. See Furman v. Georgia, 408 U.S. 238 (1972).

87. For studies of this empirical dimension of due process, see, e.g., Handler, Justice for the Welfare Recipient: Fair Hearings in AFDC-The Wisconsin Experience, 43 SOC. SERVICE REV. 12 (1969); Kirp, Buss, \& Kuriloff, Legal Reform of Special Education: Empirical Studies and Procedural Proposals, 62 Cal. L. Rev. 40 (1974). See generally Kirp, Proceduralism and Bureaucracy: Due Process in the School Setting, 28 STAN. L. REv. 841 (1976); Mashaw, The Management Side of Due Process: Some Theoretical and Litigation Notes on the Assurance of Accuracy, Fairness, and Timeliness in the Adjudication of Social Welfare Claims, 59 Cornell L. Rev. 772 (1974); Michelman, The Supreme Court and Litigation Access Fees: The Right to Protect One's Rights (pt. 1) 1973 Duke L.J. 1153 (1973); Yudof, Procedural Fairness and Substantive Justice: Due Process, Bureaucracy, and the Public Schools, in FUTURE Trends in Education Policy (J. Newitt ed. 1979) [forthcoming].

88. See Fiss, Racial Imbalance in the Public Schools: The Constitutional Concepts, 78 HARv. L. Rev. $564(1965)$. 
invariably these mutations produce undesirable results. The law becomes unstable as constitutional decisions are made to turn on the most recent social science findings. ${ }^{89}$

Instrumentalism also provides a "rationale for non-compliance and for open political attack on constitutional guarantees." 90 If due process hearings do not alter decisionmaking patterns, if desegregation does not improve black achievement, if the police are not deterred from misbehavior by the Miranda rules, then instrumentalism would counsel abandonment of the constitutional principles. The instrumental approach also undermines the legitimacy of judicial decisionmaking. If judges are to elucidate a constitutional text and history rather than to describe a "social reality and preferred policy choice,"91 or at least to make a reasonable stab in that direction, the instrumental approach would permit a substantial expansion or contraction of constitutional entitlements unlimited by such concerns. ${ }^{92}$

The instrumental approach to constitutional entitlements then rarely will make sense. It may increase the relevance of social science evidence, but such evidence will only be useful where the causal relationships under consideration are fairly simple and the variables easily identified and quantified. ${ }^{93}$ Even the price of such a limited accommodation may be a distortion of constitutional principles and constitutional decisionmaking. But what is the alternative? Members of the legal system will make decisions irrespective of their qualms about their capacity to act wisely, for it is the task of a legal system to resolve

89. See Linde, supra note 44, at 241; Equal Educational Opportunity, supra note 7, at 445.

90. Linde, supra note 44 , at 240.

91. Id. at 242 .

92. As Justice Black argued in another context, "[o]ne of the most effective ways of diluting or expanding a constitutionally guaranteed right is to substitute for the crucial word or words of a constitutional guarantee another word or words, more or less flexible and more or less restricted in meaning . . . " Griswold v. Connecticut, 381 U.S. 479, 509 (1965) (Black, J., dissenting).

93. Perhaps it should be noted that the discussion in the text focuses on "mainstream" social science research, the investigation of objective social facts and the attempt to explain those facts in terms of predictive, causal hypotheses. See generally R. Bernstein, The Restructuring òf Social and Political Theory (1978). This type of research appears to be the type most commonly proffered in judicial proceedings. But there are other schools of social science thought that are more deeply rooted in normative theory, relying on the sorts of interpretive judgments that Professor Dworkin believes judges should make. The distinction is one between an interpretative understanding (deutend verstenen) of the meaning (Sinn) of human events and a causal explanation (kausal erklären) of such events and their consequences. See M. WEBER, WIRTSCHAFT UND Gesellschaft, ch. 1 (1956). Perhaps Thomas Kuhn's book, The Structure of Scientific RevoLuTrons (2d ed. 1970) has been the most influential in this regard. Kuhn argues that the sciences are dependent on "paradigms," which determine what is to be investigated, the manner of investigation, and what constitute facts and solution. See also P. WINCH, supra note 76 . I also have found interesting the critical theories of the Frankfurt School of Marxism. See, e.g., J. Habermas, Knowledge and Human Interests (J. Shapiro trans. 1972); M. Horkheimer, Eclipse of Reason (1947). 
disputes. Judges make interpretive rather than causal judgments. They usually will not be able to rely upon policy research to establish causal links in any scientific sense, but they can locate "a particular phenomenon within a particular category of phenomena by specifying its meaning within the society in which it occurs." 94 Interpretive judgments are based on conventions and shared understandings. ${ }^{95}$ In Professor Dworkin's view, this generally means that characterizations will be made by judges after the study of the "standard legal materials," and of the society, its practices and its history. Then the interpretive judgments should be related to principles:

[W] hat political theory can we describe such that, if we accepted the political theory, these cases would therefore be justified as a matter of political morality? What do we have to assume about political rights, political goals, political morality - what do we have to assume in order to suppose that these decisions are right as a matter of political principle? ${ }^{96}$

The political morality or principles will need to be drawn from constitutional law. But in large measure, the predicates for decision would not be causal hypotheses deriving from instrumentalist reformulations of constitutional entitlements. Needless to say, there is no reason to believe, a priori, that interpretive judgments are more certain, objective, and defensible than causal judgments.

The remainder of this article explores the different ways of conceptualizing school desegregation and examines the causal hypotheses and interpretative judgments that underlie each of the alternative formulations. My purpose is twofold: to reveal the inadequacy of social science research as a means of resolving school desegregation controversies; and to demonstrate the Supreme Court's violation of standards of reasoned elaboration, that is, its inconsistency and lack of clarity in expounding principles that would justify its decisionseven where it relies on interpretive judgments. I fear that a lack of understanding as to the first point has misled social scientists into conducting research in the false hope that their efforts will influence desegregation decisions by the Supreme Court. I fear that the Court's lack of understanding concerning the second point has imposed substantial costs on it as an institution and on those subject to its decisions.

94. Dworkin, supra note 16 , at 21 .

95. Id. at 24. Arguably, Dworkin is turning judges into normative social scientists. Professor Winch argues that the making of interpretative judgments by social scientists brings them into the realm of philosophy and distinguishes their work from that of natural scientists. See Winch, supra note 76.

96. Id. at 24. This raises a general question I largely avoid-whether judges are more adept at making interpretative judgments than causal judgments. Should judges allow expert testimony on the interpretation of human events and accord it some deference? 
IV

\section{Nondiscrimination and Beyond: The Search for a Principle and the USes of Social Science Research}

If Brown stands for the proposition that school authorities may not assign students to public schools on the basis of their race to maintain a segregated school system, the simplicity of that principle is belied by the complexity of applying it in the circumstances currently facing federal judges. In the original challenges to the dual school system, discrimination was explicit and generally embodied in state law and regulations. Today, although segregated school systems are still common, the question of racial motivation is more difficult to answer as school assignments are justified on the basis of neighborhood attendance zones, overcrowding, ability grouping, parental choice, and the like. The factual and legal issues confronting the Burger Court then are more subtle than those confronting its predecessor:

The point is not to prove that the Burger Court is more or less liberal on matters of race. It has always been clear that the core of the Warren tradition-the prohibition of state-imposed segregation in public education and facilities ... remains firmly intact. But those are not generally the questions that reach the Supreme Court today. Rarely, in fact, does the race issue now appear in the context of overt and easily detected prejudice or without legitimate considerations on the other side. ${ }^{97}$

The Court must decide when facially neutral policies that produce or maintain segregated schools should be assimilated, morally and legally, to the concept of racial discrimination. ${ }^{98}$

The question of remedies, once racial discrimination in pupil assignment has been satisfactorily demonstrated, is also more complicated today than it was in the Brown era. The fashioning of constitutional remedies allows the Court greater flexibility, for rarely does the Constitution address the manner in which constitutional entitlements should be protected. The Court may experiment with a remedy and subsequently abandon it if it proves ineffective and too costly to implement or generates substantial popular and political opposition. ${ }^{99}$ While adherence to precedent and fear of institutional embarrass-

97. WILKinson, supra note 4 , at 136-37.

98. See, e.g., Graglia, supra note 7; Dworkin, supra note 1; Kaplan, Segregation Litigation and the Schools,-Part II: The General Northern Problem, 58 Nw. U. L. REv. 157 (1963); Lawrence, Segregation "Misunderstood": The Milliken Decision Revisited, 12 U.S.F.L. REv. 15 (1977); Simon, supra note 10; Note, Reading the Mind of the School Board: Segregative Intent and the De Facto/De Jure Distinction, 86 Yale L.J. 317 (1976); Wolf, Northern School Desegregation and Residential Choice, 1977 Sup. CT. Rev. 63.

99. It is not my purpose to defend the practice of taking such consequences into account, although it would be naive in the extreme to believe that efficacy, costs, and political opposition are not considered by judges-particularly in a remedial context. On the other hand, a number of scholars seek to justify judicial review in terms of a constructive dialogue between the Court 
ment may make the Court reluctant to overrule decisions articulating constitutional rights, these factors are less potent in redressing constitutional violations.

The most attractive remedy for racial discrimination is to require racial neutrality. If black youngsters are denied admission to a school that they are otherwise eligible to attend, a federal court can simply order their admission to that school and prohibit school authorities from taking race into account in the future. One major difficulty, however, as history demonstrates, is that school officials may employ surrogates for race in school assignments, such as residence, appearing to implement the nondiscrimination remedy while preserving school segregation. Thus, the problem of unmasking subtle and covert racial discrimination is compounded by the difficulty of determining compliance with the principle of nondiscrimination.

The Supreme Court has indicated its dissatisfaction with remedies that embody the nondiscrimination principle but leave segregated schools largely in place. Despite protestations to the contrary, the Court has required that the constitutional offense of deliberately segregated schools be remedied by assuring racially balanced schools within the area affected by the original wrong. ${ }^{100}$ Race must be taken into account in order to accomplish this objective, and racially neutral criteria that do not produce the desired result are not acceptable. ${ }^{101}$ This has required the Court to examine two causal questions: To what extent has present demographic segregation been caused by past, explicit racial discrimination? and: To what extent does racial discrimination in a portion of a school district or state lead to segregation in other parts of the district or state? ${ }^{102}$ In other words, when are superficially neutral criteria really racially discriminatory due to past segregative acts? Should the racial balance remedy be applied to the entire school district or metropolitan area, or should it be limited to the schools and areas in which the violations took place? Despite the statements in Brown that the dual school system is inherently harmful to black children, subsequent decisions have not relied on the hypotheses that segregated schools injure blacks, either cognitively or affectively, and that integrated schools undo such harms. Nor has the Court explicitly created a right to an integrated education.

and the other institutions of government. L. TRIBE, supra note 52, at 13. See also Chayes, supra note 55 .

100. See, e.g., Swann v. Charlotte-Mecklenburg Bd. of Educ., 402 U.S. 1 (1971), permitting the district court to use mathematical ratios for each school which reflected the proportions of each race in the school system as a whole, although the Court noted that " $[t]$ he constitutional command to desegregate schools does not mean that every school in every community must always reflect the racial composition of the school system as a whole . . ." Id. at 24 .

101. See, e.g., Green v. County School Bd., 391 U.S. 430 (1968). L. TRibe, supra note 52. See also Chayes, supra note 55.

102. See, e.g., Keyes v. School Dist. No. 1, 413 U.S. 189 (1973); Milliken v. Bradley, 418 U.S. 717 (1974). 
The Court has failed to justify clearly its apparent expansion of the definition of intentional segregation and its requirement of racial balance or dispersion of the races in the public schools. However, there are three possible justifications for this remedy. First, integration is necessary to remedy the present and past wrongs of racial discrimination, meaning that the public schools would have been integrated but for those wrongs. More expansively, it may mean that the public schools would have been integrated but for discrimination in public and private housing, school assignments, and employment. Alternatively, integration is necessary to undo educational, stigmatic, or other injuries to black children caused by past segregation. Second, racial balance is required because of the fear that government decisions will be corrupted by racial discrimination, however well hidden:

In a community that has settled prejudice of one sort or another . . . the [political process] machine will inevitably break down because there is no way of excluding these preferences based on prejudice from affecting the process. If prejudicial preferences are counted, then the personal preferences of those against whom the prejudice is directed are not counted equally in the balance; they are discounted by the effect of the prejudice. . .

A constitutional right is created among other reasons for this reason: We know that there is a high antecedent probability that the political judgment reached about a particular matter will not fairly reflect the kind of preferences that rightly make up the general welfare, but will give influential expression to preferences based on prejudice. We create constitutional rights of one sort or another to guard against this. ${ }^{103}$

Third, concern for the welfare of blacks as a group and an interpretive judgment about their historic treatment leads to the conclusion that integration and not just nondiscrimination should be fostered by constitutional decisions under the fourteenth amendment. ${ }^{104}$

The difficulty with the Court's remedial theory, articulated in the desegregation cases of the past decade-that school districts must racially balance their schools in order to remedy past and present discrimination-is that it appears to rely upon causal hypotheses that are difficult to support. In its strongest form, the hypothesis is "if there had not been de jure segregation in the past, there would now be de facto integration." 105 Somewhat weaker is the hypothesis that "past . . . de jure segregation may be presumed to be part of the causal chain that has produced (perhaps through affecting residential patterns, perhaps in other ways), de facto segregation of today." 106 The concept of remedy would be similar to that found in contract law: remedies should be

103. Dworkin, supra note 16 , at 28-29.

104. See generally Equal Educational Opportunity, supra note 7. See also Fiss, supra note 17.

105. Dworkin, supra note 16 , at 27.

106. Id. 
designed to put the innocent parties (black children) in the position that they would have occupied (integrated schools) but for the wrongful conduct (racial discrimination) of the defendants (school authorities). ${ }^{107}$

In theory, the investigation and illumination of such causal links should be the stuff of social science, since the constitutional questions have been formulated in instrumental terms. But there are manifest problems with this remedial theory. Whatever the theoretical scope of social science inquiry, the complexity of these causal links is such that it is unlikely that social science methodologies will ever allow the drawing of such causal inferences with a reasonable degree of confidence. Indeed, the evidence and research thus far accumulated suggests the implausibility of the "but for" theory, although there is no consensus among researchers. ${ }^{108}$ The reasons for segregated schools are complex, involving not only discrimination in schools, but also socioeconomic isolation, choices to live among people of the same race, employment discrimination, preferences among public goods, and public and private housing discrimination. ${ }^{109}$ The primacy of de jure discrimination in the segregated pattern of schools, or even its influence, is not at all clear. Furthermore, the remedial theory violates the very principle it seeks to vindicate -the principle of non-discrimination.

The Court's theory becomes more attenuated as black children today are reassigned to integrated schools as a remedy for discrimination against past generations of black students. One set of persons constitutes the class of victims of the discrimination, while another set constitutes the class of beneficiaries of the remedy. The school board that implements the court-ordered remedy may well be an entirely different board than the one that committed the original wrong. Moreover, the traditional theory of remedies assumes that the relief granted will bring about an improvement in the current situation created by the breach of a legal obligation, or the wronged party would be unlikely to seek legal redress. But the evidence that blacks are better off in

107. Cf. Milliken v. Bradley, 433 U.S. 267 (1977).

108. See, e.g., Farley, Residential Segregation and its Implications for School Integration, 39 LAw \& Contemp. Prob., Winter 1975, at 164, 174-77. O. Duncan, H. Schuman, \& B. Duncan, Social Change in a Metropolitan Community 108, Table 48 (1973); Pettigrew, Attitudes on Race and Housing: A Social-Psychological View, in Segregation in Residentral Areas 21, 44-45, Table (A. Hawley \& V. Rock eds. 1973). See also Campbell \& Schuman, Racial Attitudes in Fifteen American Cities, in The National Advisory Commission on Civil Disorders, Supplemental Studies for the National Advisory Commission on Civil Disorders 16, Table II-6 (1968).

109. See Goodman, supra note 13; Wolf, Northern School Desegregation and Residential Choice, supra note 14, at 62. But see Milliken v. Bradley, 418 U.S. 717, 779 (White, J., dissenting) (". . . had the Detroit school system not followed an official policy of segregation throughout the 1950 s and 1960 s Negroes and whites would have been going to school together."). Compare with Regents of the Univ. of Calif. v. Bakke, 438 U.S. 265, 296 n.36 (1978). (A speculative leap is required to conclude that "but for this discrimination by society at large, Bakke "would have failed to qualify for admission' because Negro applicants would have made better scores.") 
integrated schools (in academic, psychological, or other terms) is mixed. ${ }^{110}$ Finally, the vindication of the constitutional interest is made to turn on the vagaries of empirical research, with all the attendant instability and difficulties that this imports into the law.

A more expansive view of the theory, one not yet adopted by the majority of the Court, is that integration of the public schools is necessary, not simply because of past de jure practices in the public schools, but as a means of undoing the accumulated discrimination in both the private and public sector. The theory has particular appeal if government is held accountable not only for its own acts of racial discrimination but also for tolerating or permitting racial discrimination by private individuals and entities. ${ }^{111}$ The predicate for the theory strikes me as sound: there is no denying the sorry and sordid history of discrimination practiced against black people in virtually all aspects of political, social, and economic life. The difficulty is in moving from the predicate to the conclusion. Why should only school-related racial discrimination trigger the remedy of integration if it is simply one of many wrongs suffered by blacks? More importantly, in what sense does school integration or dispersion of the races make up for employment or housing discrimination, discrimination in the enforcement of criminal laws, social ostracism and the like?112 This theory is supported only by the assumption that school integration leads to progress for blacks in these other areas. This assumption, however, has the same deficiencies as the other instrumental approaches to the remedial theory.

Rephrasing the remedial theory in interpretive terms makes it more plausible: segregation in the public schools is stigmatizing and symbolic of a hostile

110. See, e.g., National Opinion Research Center, Southern Schools: An Evaluation of the Effects of School Dsegregation and of the Emergency School Assistance Program (1973); N. ST. John, School Desegregation: Outcomes for Children (1975); M. Weinberg, Minority Students: A Research Appraisal (1977); Cohen, Pettigrew, and Riley, supra note 27; Crain \& Mahard, Desegregation and Black Achievement, 42 LAw \& Contemp. ProB., Summer 1978 at 17; Dworkin, supra note 16; Equal Educational Opportunity, supra note 7. The Supreme Court has not, however, declared that it relies on any such evidence in requiring dispersal of the races.

111. The question whether discriminatory actions of government agencies other than school boards which may have contributed to the pattern of segregated schooling can trigger a school desegregation remedy was expressly reserved for future decision in Swann, 402 U.S. I, 23 (1971). In Milliken $I$, the majority noted that since the circuit court's decision had not rested on any testimony with regard to segregated housing, "the case [did] not present any question concerning possible state housing violations." Milliken v. Bradley, 418 U.S. $717,728 \mathrm{n} .7$ (1974). It is thus unclear whether the Court would ever order school desegregation if all that were shown was that nonschool governmental agencies, along with private individuals, had caused the segregated residential patterns. But see 418 U.S. at 755 (Stewart, J., concurring), "Were it to be shown ... that state officials had contributed to the separation of the races. . . by purposeful racially discriminatory use of state housing or zoning laws, then a [desegregation] decree calling for transfer of pupils ... might well be appropriate."

112. "One vehicle can carry only a limited amount of baggage." Swann v. CharlotteMecklenburg Bd. of Educ., 402 U.S. 1, 22 (1971). 
attitude by powerful whites against relatively powerless blacks. The issue, then, is not one of causal relationships but of the impact of the current patterns of racial isolation in public schools. ${ }^{13}$ If integrated schools remove the stigma and symbols of inferiority, integration is a justifiable remedy for discrimination. However, unless it is assumed that white and black Americans view all racial isolation as indicative of the racial inferiority of blacks-a dubious proposition-even this noninstrumental refinement of the remedial theory poses difficulties. If there is no evidence that segregation is the result of racial prejudice, then why should racial separation be deemed harmful to blacks? Even if there has been official racial discrimination in the past, if there is little causal connection between that and present racial isolation, should such isolation be interpreted as injurious to blacks? One might be able to construct a theory that adventitious segregation is more stigmatizing in a school district that previously practiced explicit discrimination, ${ }^{114}$ but intuitively this strikes me as unsound. ${ }^{115}$ Such reformulations of the remedial theory are based either in notions of the corruption of the political process or of the affirmative value of integration for its own sake.

Professor Dworkin, wishing to avoid the causal relationship quagmire, justifies integration as a prophylactic device designed to overcome the high probability that superficially race-neutral decisions that result in segregation are the result of a corrupt process of government decisionmaking. ${ }^{116}$ The corruption flows from the interpretive judgment that blacks have not made such decisions for themselves and that racial prejudice remains rampant. His view finds little support in judicial opinions. Perhaps the case that can be most easily construed to support Dworkin is Green v. County School Board, ${ }^{117}$ the first Supreme Court opinion pointing toward an integration rather than a nondiscrimination remedy.

In Green, as in Brown, school authorities had explicitly assigned students to schools on the basis of their race. After these policies had been declared unconstitutional, the school board adopted (and the lower court approved) a so-called freedom of choice plan permitting black and white parents to choose the schools that their children were to attend. Segregation was perpetuated, a

113. See Lawrence, supra note 98.

114. See generally Goodman, supra note 13 , at 295.

115. A majority of the Supreme Court has indicated that even formerly de jure school districts can free themselves from the taint of their past wrongful acts and will be under no continuing duty to eliminate adventitious segregation. The Court has failed, however, $t$ articulate any guidelines for determining when and under what circumstances a school district has achieved this status. Spangler v. Pasadena City Schools, 427 U.S. 424, 441 (1976); Keyes v. School Dist. No. 1, 413 U.S. 189, 211 (1973); Swann v. Charlotte-Mecklenburg Bd, of Educ,, 402 U.S. 1, $31-32$ (1971).

116. See Dworkin, supra note 16.

117. 391 U.S. 430 (1968). See also Raney v. Board of Educ., 391 U.S. 443 (1968); Washington Parish School Bd. v. Moses, 456 F.2d 1285 (5th Cir. 1972). 
result which was readily predictable when the plan was adopted. The schools remained racially identifiable in terms of faculty, staff, and student assignments. The Supreme Court held that, in the circumstances of the case, the plan was constitutionally insufficient to disestablish the dual school system. Interestingly enough, fairly drawn and compact neighborhood attendance zones for New Kent County's two schools would have led to substantial integration. ${ }^{118}$ Only a fool would need to search the official records for evidence of racial prejudice under such circumstances. It seems obvious that public officials rejected more traditional geographic and perhaps other criteria for assigning pupils precisely because they believed that the freedom of choice approach would maintain segregation. This is an interpretive judgment, a characterization of behavior, not based upon proof of causation in the sense of objective evidence of a subjective intent to discriminate. Thus, in Green it is hardly hyperbolic to speak of the local board's decisions as being corrupted by racial prejudice. The freedom of choice plan would not have been adopted but for racial prejudice, and the significance of racial prejudice in governmental decisionmaking itself constitutes a stigmatic harm to blacks. ${ }^{119}$

The difficulty with the corruption theory, even if one assumes that it accurately describes the pervasiveness of prejudice and the relative powerlessness of blacks, lies in formulating the appropriate remedy. In Green the Court did not order the implementation of a neighborhood pupil assignment policy; rather it dwelled on the idea of compelling school districts to adopt plans that promised to work-working apparently meaning that some substantial progress had to be made toward achieving racial balance in the schools. The Court moved to an outcome remedy for a constitutional wrong rooted in the decisional process. Professor Dworkin, however, is prepared to defend such integration remedies even though he characterizes them as "arbitrary." Lest I misstate his argument, perhaps I should let him speak for himself:

Suppose, however, that . . prejudice has not lessened much and blacks do not have the kind of political power that would cancel any antecedent probability of corruption. What else would persuade us to disregard that probability in any particular case? Only one thing: the outcome. If the decision actually produced by the political process was of a sort itself to negate the change [sic] of corruption, then we could withdraw, for that case, the judgment that the process was too corrupt to allow it to continue.

We must understand a court order to integrate, even an order based upon a mechanical formula that otherwise has no appeal, in the following way. The order speaks to those in political power and says this: "If you refuse yourself to produce an outcome that negates the antecedent probability of corruption, then we must impose upon you such an outcome. The only decision that we

118. L. Graglia, supra note 7, at 77-78.

119. See generally Simon, supra note 10. 
can impose, given the nature of the problem, is a decision that requires integration on some formula that is evidently not corrupt even if it is just as evidently arbitrary."

If I am right, then objections to these decisions based on doubt about the various causal hypotheses I identified are misguided, because these decisions do not rest on causal hypotheses. They rest on interpretive theory. Until the background changes in one of the two ways I suggested-until our sense of prejudice abates or blacks have the political power to make decisions in question-until that happens, then integration is required as the only thing that can sustain the burden of proof rising from the antecedent probability of corruption. ${ }^{120}$

What is baffling about Dworkin's theory is not its predicate but its conclusion. While it is true that sometimes predominantly black and integrationminded school boards have been charged with de jure segregation and held to a racial balance remedy, the notion that many school boards hide behind superficially neutral criteria, when they are actually influenced by racial prejudice, seems entirely plausible. If the observation is rephrased to argue that board members rarely assign a positive value to racial integration in making decisions, the observation is essentially irrefutable. There appears to be no rush to relieve overcrowding, to construct new schools and remodel old ones, or to determine neighborhood attendance zones or feeder patterns for junior and senior high schools in a manner likely to advance integration. But why should the failure to treat integration as a positive value injure blacks? How is it stigmatizing? Green is far removed from this situation. There, the policies resulting in segregation would not have been adopted but for racial prejudice. Perhaps in such cases the "arbitrary" remedy of racial dispersion has some merit. It is a guarantee that racial prejudice is not at work, although it is also a guarantee that race will be taken into account. Even in these circumstances, however, the outcome remedy is not compelling. The harm could be undone by requiring school districts to adopt those racially neutral policies, such as the choice of school construction sites and the drawing of attendance zone boundaries that most advance racial integration. ${ }^{121}$ The corruption and hence the stigma could be relieved without mandating a race-conscious policy of racial balance as the remedy.

The more common fact pattern probably lies between the two extremes of failing to promote integration and of taking an action that would not have been taken but for racial prejudice. People and institutions act for many reasons and combinations of reasons, and racial prejudice may be only one factor. ${ }^{122}$

120. Dworkin, supra note 16 , at 30 , (italics in original).

121. See, e.g., Keyes v. School Dist. No. 1, 413 U.S. 189, 226 (1973) (Powell, J., concurring and dissenting); Crawford v. Board of Educ., 17 Cal. 3d 180, 305-06, 551 P.2d 28, 45, 130 Cal. Rptr. 724, 741 (1976); Simon, supra note 10, at 1122-27.

122. See, e.g., Kirp, et al., supra note 15. 
An action that a court finds was in any significant way prompted by prejudice is definitionally insulting, and for this reason proof that the action was so prompted simultaneously establishes a dignitary harm. Whether the plaintiff should be granted relief with respect to other harms produced by such an action is a more complicated question. The complication arises from the possibility that although racial prejudice did play some role, the governmental entity might have taken the same action even apart from prejudice. ${ }^{123}$

If a neighborhood schools policy-resulting in segregation because of current residential patterns-would be the preferred policy, even if every trace of racial prejudice were magically eliminated, what justification is there for putting black students in a "better" position than they would have occupied if there had been no racial prejudice?

Dworkin apparently agrees with Simon "that once an action is proven to have been affected-or even potentially affected-by racial prejudice, the question whether the same action would have been taken apart from prejudice should be simply irrelevant." 124 But it is relevant to a remedy premised on the necessity of undoing the harm of racial prejudice. At best, plaintiffs should be entitled to the remedy of racial mixing to the extent that other policy objectives are not impeded. Or school officials should be ordered to reconsider their other policies without reference to racial prejudice. ${ }^{125}$ The harm is the insult of taking racial prejudice into account, not the failure to achieve integration. What then is the justification for doing more, particularly if the segregation does not give rise to significant instrumental harms?

Dworkin, with his customary breadth of vision, attempted a tour de force in explaining and justifying modern desegregation decisions. He sought to vindicate a process interest through an outcome remedy, while declining to be taken in by a fragile instrumentalism. In this, he has not succeeded. All that is left is a theory based on the outcomes themselves: both constitutional wrong and remedy rooted in the failure to achieve integration. This theory is premised on the interpretive judgment that segregation itself is the evil and that integration is necessary to undo that evil. ${ }^{126}$ Adherence to this theory is an extension of traditional equal protection analysis in race cases, an extension that a number of commentators have found troubling. ${ }^{127}$ On the other hand, the theory does not rely on the instrumental premises of the remedial theory, such as the idea that segregated education impedes the achievement of black

123. Simon, supra note 10, at 1054. Compare Regents of the Univ. of Calif. v. Bakke, 438 U.S. 265, 294 n.34 (1978) (Powell, J.) ("The Equal Protection Clause is not framed in terms of 'stigma.' Certainly the word has no clearly defined constitutional meaning. It reflects a subjective judgment that is standardless.")

124. Id. at 1059 .

125. Id. at 1126 .

126. See generally Equal Educational Opportunity, supra note 7.

127. See, e.g., Brest, supra note 5, at 44-52 (1976). 
youngsters, but on the interpretive judgment that affirmative values such as racial peace and equality between the races are not attainable so long as the races are physically separated in important private and public institutions. ${ }^{\mathbf{1 2 8}}$ In this sense, it is a judgment about history and about the sort of society to which we should aspire. Separation-insularity-of blacks has left them open to the full measure of white hostility. ${ }^{129}$ Integration of public schools is justified not because of prejudice against individuals but because of the need to protect a racial group against the historical forces that have isolated and hence oppressed it. Integration is part and parcel of the undoing of a caste system that has consistently disadvantaged black Americans.

The Supreme Court, however, has failed to justify a racial balance remedy under any of the foregoing theories. Indeed, it has done all that is within its power to obfuscate the underlying bases of its decisions. In some cases, the vigor with which the racial balance remedy is pursued suggests the group protection theory for integration. The language of the opinions, however, often indicates otherwise. At times some of the Justices have used social science research to prove or disprove the causal assumptions of the remedial theory, ${ }^{130}$ while at other times they have declined to rely upon such evidence. ${ }^{131}$ They have created evidentiary presumptions about school board decisions-seemingly reflecting a view that governmental processes are likely to be corrupted by racial prejudice-and then ignored such presumptions in subsequent cases. ${ }^{132}$

There is surely some merit in the common law method: deciding one case at a time, answering questions no broader than are absolutely necessary, and thus preserving flexibility. But caution and flexibility are not synonymous with incoherence, the incoherence generated by the failure of many justices to understand and articulate the doctrinal alternatives and by the willingness to patch over differences in a sensitive area laden with symbolism. This confusion is fed by changes in the philosophical bent of the Court, by the absence of intellectual leadership, and by a heightened sensitivity to the political climate.

A majority of the justices have relied on the nondiscrimination principle to justify particular remedies. Yet there are sharp divisions among them about the propriety of requiring racial balancing, the circumstances in which this remedy should be required, and the scope of that remedy. The real differ-

128. See generally Equal Educational Opportunity, supra note 7 .

129. See generally M. Yudof \& D. Kirp, Paternalism and Gender Policy (1978) (unpublished manuscript).

130. See, e.g., Milliken v. Bradley, 418 U.S. 717 (1974).

131. See, e.g., Swann v. Charlotte-Mecklenburg Bd. of Educ., 402 U.S. 1 (1971).

132. Compare Keyes v. School Dist. No. 1, 413 U.S. 189 (1973), with Dayton Bd. of Educ. v. Brinkman, 433 U.S. 406 (1977). 
ences among the justices probably have little to do with the nuances of legal remedies. Some members of the Court have a profound distrust for the administrative and legislative processes of the states, while others consider it to be their divine mission to protect local and state governments from the incursions of Congress and the federal judiciary. The former are more likely to see racial prejudice as a factor in those government decisions justified on racially neutral grounds, while the latter are inclined to give government officials the benefit of the doubt. ${ }^{133}$ Some justices appear to attach a positive value to integration-and a negative value to segregation-while others seem concerned only with alleviating specific harms. ${ }^{134}$ There also is disagreement on what counts as an unacceptable level of costs (social, political, and economic) to implement a racial balance remedy. ${ }^{135}$ But with a few exceptions, there has been a lack of candor in explaining the reasons for desegregation decisions.

The unwillingness of both the Burger and Warren Courts to confront openly the essential and unavoidable choice among the remedial, corruption, and group protection principles for resolving the school segregation cases has led to a variety of consequences, none of them good. First, by failing to be forthright, the Court has compromised its integrity and capacity for moral leadership. Second, there has been a tremendous loss of certainty in the law, as the Burger and Warren Courts dangle the same nondiscrimination and remedial principles to reach inconsistent results. ${ }^{136}$ The lack of predictability about a particular outcome imposes severe transaction costs as lower courts and school districts scramble to comprehend what they are required to do. And the existence of doubt leaves lower courts free to go their own way in factually indistinguishable cases.

Third, enormous damage has been done to the cause of those who would opt for the group protection or corruption principles in lieu of remedial theories, which simply will not suffice to support racial balance outcomes. The Court, and many seriously misled commentators, appear afraid to broach their principle for fear of the adverse consequences that would follow. A principle that is not cogently articulated and elaborated in a reasoned fashion, but tucked away in the nuances of an opinion, reinforces the notion that the

133. See, e.g., Arlington Heights v. Metropolitan Housing Development Co., 429 U.S. 252 (1977); Washington v. Davis. 426 U.S. 229 (1976); Palmer v. Thompson, 403 U.S. 217 (1971).

134. Compare Keyes v. School Dist. No. 1, 413 U.S. 189, 214 (1977) (Douglas, J., concurring) with 413 U.S. 189, 254 (Rehnquist, J., dissenting). See also Milliken v. Bradley, 418 U.S. 717, 781 (1974) (Marshall, J., dissenting).

135. See, e.g., Milliken v. Bradley, 418 U.S. 717, 781 (1974) (Marshall, J., dissenting); Keyes v. School Dist. No. 1, 413 U.S. 189, 226 (1973) (Powell, J., concurring and dissenting).

136. See, e.g., Dayton Bd. of Educ. v. Brinkman, 433 U.S. 406 (1977); Keyes v. School Dist. No. 1, 413 U.S. 189 (1973). But see Taylor, The Supreme Court and Recent School Desegregation Cases: The Role of Social Science in a Period of Retrenchment, 42 LAw \& Contemp. Pros., Autumn 1978, at $45-48$, for the argument that Dayton is not a departure from Keyes. 
principle is not defensible at all. This permits those who disagree with the results of earlier cases moving the nation closer to integration to rely on the precise language of the earlier opinions to reach contrary results. ${ }^{137}$

Finally, the failure to articulate the competing corruption and group protection theories has, in my view, serious consequences for social policy research. Social scientists will be and are sorely tempted to follow the false lines of instrumental analysis articulated by the Court in a remedial framework, when ultimately interpretive judgments are dispositive of the school integration issue. Research that tries to sort out such causal connections as the sort of school system that would have existed but for some proven past discriminatory acts and the impact of integration on student achievement may be worthwhile in its own right, but there should be no expectation of a direct and substantial impact on judicial decisions. Perhaps if the evidence pointed unequivocally in one direction or the other, judges would turn to it. But the last twenty-five years do not bode well for the surfacing of such clear-cut findings.

My point is that judicial responses to race and school cases will not turn on the evidence adduced by social scientists, but on the Court's perception of what American society is like today and what its aspirations should be for the future. ${ }^{138}$ Given the broad nature of the propositions to be tested, the methodological difficulties, the value judgments inherent in each approach, and the nonconvergent trends of social science research, social science will have little impact on the resolution of the central dilemmas. At best, it will provide an after-the-fact justification for a decision reached on other grounds. The pity is that the court has encouraged research by holding out the carrot that empirical studies on housing discrimination, white flight, and other factors bearing on the etiology of present demographic patterns will carry the day. ${ }^{139}$

The evolution of desegregation law since the Court's 1971 decision in Swann v. Charlotte-Mecklenburg Board of Education, ${ }^{140}$ some three years after Green, illustrates my point. In Charlotte-Mecklenburg there had been a long history of separation of the races in the public schools, but in 1965 the lower courts approved a plan based upon geographic zoning accompanied by a free transfer program. The school district had achieved a unitary school system, at least in terms of an official policy of nondiscrimination by race. Yet in 1969 the matter was reopened because approximately two-thirds of the 21,000

137. See, e.g., Dayton Bd. of Educ. v. Brinkman, 433 U.S. 406 (1977) (Rehnquist, J., for the Court); Austin Indep. School Dist. v. United States, 429 U.S. 990, 992 (1976) (Powell, J., concurring); Keyes v. School Dist. No. 1, 413 U.S. 189, 258 (1973) (Rehnquist, J., dissenting).

138. But see Taylor, supra note 136 , at 39 , for the argument that social science evidence "may have a real impact on the context in which justices approach future cases-that is, their perception of social reality ...."

139. See especially, Milliken v. Bradley, 418 U.S. 717, 755 (1974) (Stewart, J., concurring).

140. 402 U.S. 1 (1971). 
black students in the City of Charlotte attended schools that were 99 percent or more black. Chief Justice Burger, in an enigmatic opinion that can be cited for virtually any proposition, emphasized that the Court was laying down guidelines for lower courts and boards of education in remedying past discrimination: federal judicial power may be exercised "only on the basis of a constitutional violation," and "the nature of the violation determines the scope of the remedy."141

While denying that racial balance in each school was required or desirable, ${ }^{142}$ the Swann Court affirmed a wide-scale busing plan, which largely accomplished that result. Why is this the appropriate remedy? What is the relationship between the old dual school system and present segregated residential patterns in Charlotte ${ }^{143}$ Were the present policies tainted by racial prejudice? To what extent? If there were no present discrimination, how would integration for students attending Charlotte's schools today remedy injuries inflicted in the past upon their parents and grandparents? If the burden of disproving these propositions is placed on school boards, ${ }^{144}$ is this not tantamount to adopting a racial integration principle? Consider these remarks by Professor Fiss on the Swann case:

The net effect of Charlotte-Mecklenburg is to move school desegregation further along the continuum toward a result oriented approach. ... [I]n retrospect, Charlotte-Mecklenburg will then be viewed . . . as a way station to the adoption of a general approach to school segregation which, by focusing on the segregated patterns themselves, is more responsive to the school segregation in the North.

The forecast is based ... on my view that the predominant concern of the Court in Charlotte-Mecklenburg is in fact the segregated pattern of student attendance, rather than the causal role played by past discriminatory practices ... . The Court made no serious attempt either to determine or even speculate on the degree to which it contributes to present segregation. Nor did the Court attempt to tailor the remedial order to the correction of that portion of the segregation that might reasonably be attributable to past discrimination. The Court moved from (a) the undisputed existence of past discrimination to (b) the possibility or likelihood that the past discrimination played some causal role in producing segregated patterns to (c) an order requiring the complete elimination of those patterns. The existence of past discrimination was thus used as a "trigger" -and not for a pistol, but for a cannon. Such a role cannot be defended unless the primary concern of the Court is the segregated patterns themselves, rather than the causal relation of past discrimination to them. The attention paid to past discrimination can be viewed as an attempt by the Court to preserve the continuity with Brown and to add a moral duality to its decisions. ${ }^{145}$

141. Id. at 16 .

142. Id, at 24 .

143. Id. at $20-21,28$.

144. Id. at 26.

145. Fiss, The Charlotte-Mecklenburg Case-Its Significance for Northern School Desegregation, $38 \mathrm{U}$. Chi. L. Rev. 697, 704-05 (1971) (italics added); L. Graglia, supra note 7, ch. 7. See generally Goodman, supra note 13. Equal Educational Opportunity, supra note 7. 
The argument that the Court was moving toward integration per se rather than simply remedying past acts of discrimination is reinforced by the Keyes decision. ${ }^{146}$ Keyes was the first Northern desegregation case to reach the Supreme Court and the majority, relying on a remedial theory similar to Swann, ordered the integration of the public schools of Denver. There are a number of interesting aspects of the case. The discrimination that allegedly occurred consisted of some relatively isolated events, nearly all of which fall into the category of purportedly racially neutral policies with segregative effects. These included the gerrymandering of attendance zones, the use of optional zones, the excessive use of mobile classrooms, and the construction of a new elementary school in the middle of one of the black areas of Denver. ${ }^{147}$ Most of the evidence showed a pattern of failing to take action to alleviate segregation, rather than showing that the school system was pursuing an independent segregationist policy.

Denver never had set up or maintained a dual school system such as those so prevalent in the pre-Brown South and border states. ${ }^{148}$ Perhaps the Keyes Court concluded that the cumulative circumstances indicated that racial prejudice was a factor in the board's policy decisions. If so, this conclusion is questionable, since the board then in power had passed three resolutions that sought "to desegregate the [predominantly black] schools in the Park Hill area ...."149 Thus corruption by racial prejudice could only have entered the picture when the electorate replaced the board majority that had adopted these resolutions and "the resolutions were rescinded [by the new board] and replaced with a voluntary student transfer program"150 that showed little promise of integrating the public schools of Denver. Yet, the Court did not rely on the rescission of the earlier resolutions, and it is doubtful that it would have supported a systemwide racial balance remedy in any event. ${ }^{151}$

The district court, which had based its finding of de jure segregation in the Park Hill area on the fact of the rescission, ${ }^{152}$ held that the substantial segregation in the core of Denver had been brought about by deliberate policies of segregation. ${ }^{153}$ The Supreme Court nonetheless held that there was

\footnotetext{
146. 413 U.S. 189 (1973).

147. 413 U.S. at 192. Desegregation Research, Dec. 5, 1977.

149. 413 U.S., at 192 (1973). See L. Graglia, supra note 7, at 162

150. 413 U.S., 189, 192 (1973). See L. Graglia, supra note 7, at 163-64.

151. See L. Graglia, supra note 7, at 168-69.

152. 303 F. Supp. 279, 287 (1970).

153. 313 F. Supp. 61, 73 (1970).
}

148. L. Graglia, supra note 7, at 161. "Not only was separation according to race never required in the Denver schools, but it was from the beginning explicitly prohibited by the Colorado constitution.") Other commentators, however, strongly disagree with this view of the actions of the Denver School Board. See, e.g., Letter from Norman J. Chachkin, Senior Staff Attorney, Lawyers' Committee for Civil Rights under Law, to the National Review Panel on School 
a presumption that unlawful segregation in one portion of the district had a significant impact on other parts of the district, and that proof of unlawful segregative intent with respect to some acts created a presumption that other acts, perhaps unexceptionable in another context, were also motivated by some illicit, racially discriminatory motive. ${ }^{154}$ This again sounds like the corruption theory. The difficulty with the formula, apart from questions about its reliance on a finding of past de jure conduct, is that the segregation in the core area preceded the allegedly unlawful acts in Park Hill, and therefore could not possibly have caused it. ${ }^{155}$

Despite the language of the opinion, Keyes can only be explained on the basis that school districts have an affirmative duty to integrate or that undoing plans to integrate students constitutes enough evidence of racial prejudice to justify a racial balance remedy. No justice relied on the latter theory. Justices Douglas and Powell, however, did rely on the former theory in separate opinions. ${ }^{156}$ There simply was no competent proof of widespread discrimination in the record, unless the definition of discrimination is expanded to include all actions or failures to act that promote or reinforce existing segregated patterns. There certainly was little evidence connecting specific wrongful acts to the degree of segregation existing in Denver. ${ }^{157}$ The Court simply speculated on these points, failed to rely on a significant body of research, and conveniently allocated the burden of persuasion to the alleged wrongdoer, the school district. Further, the Court made no real effort to match the remedy with the

154. 413 U.S. at 208.

155. L. Graglia, supra note 7 , at 182

The core city schools were black or nearly black long before the Park Hill schools began to change from whice to black. It is difficult to understand how the board actions that supposedly caused the "segregation" in Park Hill could have caused or contributed to the earlier "segregated condition of the core city schools"-in fact, the district judge had not found those actions had caused even the "segregation" in Park Hill.

156. Keyes v. School Dist. No. 1, 413 U.S. at 215,224 (1973).

157. See L. Graglia, supra note 7, at 168-72.

The district judge left no doubt that his findings as to the Park Hill schools were supplemental to and entirely dependent upon his finding that the rescission was unconstitutional. He refused to find that any racially imbalanced school not affected by the rescission was "de jure segregated" and he found unconstitutionality in connection with all schools-those in Park Hill-that were affected. He explicitly relied on the rescission in his findings as to each Park Hill school and he relied on nothing else in his findings as to some of them. .

The panel of the Tenth Circuit that reviewed the district judge's first two opinions ... found:

... No discrimination in school transfers was either show'n or claimed. No gerrymandering was shown or claimed. The district court's findings of de jure segregation . . . were confined to a small number of schools and were based on the failure or refusal of the School Board to anticipate population migration and to adjust school attendance districts to alleviate the imbalance resulting from such population shifts. [Citation omitted.]

L. Graglia, supra note 7, at 172, 173. See Keyes v. School Dist. No. 1, 445 F.2d 990, 998 (10th Cir. 1971). 
wrong. It did not ask what the racial composition of Denver's schools would have been if the discriminatory acts had not been committed. It did not adopt a remedy that would undo only that increment of segregation caused by the discriminatory acts. ${ }^{158}$ Without relying on any social science evidence, without articulating, elaborating, or defending a corruption or group protection theory, and without any real admission that it was going beyond Brown, the Court implied that the Equal Protection Clause of the fourteenth amendment mandates integration of the races in the public schools. ${ }^{159}$

Lower courts apparently had some difficulty interpreting the command of Keyes, some emphasizing what the Supreme Court had said and others emphasizing what it had done. The result was that vastly different standards for determining the existence of and the appropriate remedies for de jure segregation were applied by different federal judges in different parts of the country, though the trend was toward systemwide integration. Over the dissents of Justices White and Powell, the Supreme Court simply ignored this phenomenon by denying petitions for writs of certiorari in cases raising questions about these inconsistencies. ${ }^{160}$

One year and one month after Keyes, the Court, in Milliken $v$. Bradley, ${ }^{161}$ rejected a metropolitan-wide remedy for Detroit's de jure segregated public school system. There were insufficient white students in Detroit to integrate its public schools, and hence integration-dispersing black students to majority white schools-could be accomplished only by including the surrounding predominantly white suburban districts in the plan. Milliken signalled that the days of unanimity or near unanimity in desegregation cases in the Supreme Court were over. ${ }^{162}$

158. Compare Austin Indep. School Dist. v. United States, 429 U.S. 990, $991-2$ (1976) (Powell, $\mathrm{J} .$, concurring).

159. The closest the majority came to grappling with this issue was. ironically, in a footnote: Our brother Rehnquist argues in dissent that Brown $v$. Board of Education did not impose an "affirmative duty to integrate" the schools of a dual school system but was only a "prohibition against discrimination" "in the sense that the assignment of a child to a particular school is not made to depend on his race...." [citation omitted]. That is the interpretation of Brown expressed 18 years ago by a three-judge court in Briggs $v$. Elliott "The Constitution, in other words, does not require integration. It merely forbids discrimination." But Green v. County School Board . . . , rejected that interpretation insofar as Green expressly held that "School boards . . operating state-compelled dual systems were nevertheless clearly charged [by Brown II] with the affirmative duty to take whatever steps might be necessary to convert to a unitzicy system in which racial discrimination would be eliminated root and branch." Green remains the governing principle. [Citing, inter alia, Swann].

413 U.S., at 200-01. n.11.

160. See, e.g., Medley v. School Bd., 482 F.2d 1061 (1973), cert. denied, 414 U.S. 1172 (1974) (White, J., and Powell, J., dissenting); Goss v. Bd. of Educ., 482 F.2d 1044 (6th Cir. 1973), cert. denied, 414 U.S. 1171 (1974) (White, J., and Powell, J., dissenting).

161. 418 U.S. 717 (1974).

162. This was the first time since Missouri ex rel. Gaines, 305 U.S. 337 (1938), that the posi- 
The Court could easily have refused to require the amalgamation of separate school districts in Milliken, without undermining the Swann and Keyes precedents, by noting that restructuring local governmental entities, redrawing political boundary lines and drastically altering their operations create unacceptably high costs in terms of federalism to accomplish the objective of integration. In other words, every principle of constitutional law, and certainly the fashioning of remedies in desegregation suits, must know some limits. Courts sometimes say that costs are irrelevant in the vindication of constitutional rights, but in the real world this cannot be the case. Recognizing this, Justices Harlan and Clark expressed reservations about the power of federal courts to require school districts to reopen their doors and raise and expend revenues to operate a desegregated school system. ${ }^{163}$ Justice Powell said as much in his concurring and dissenting opinion in Keyes. ${ }^{164}$

The Milliken Court, however, declined to engage in this sort of analysis to any significant extent. Rather, the Court's opinion reflects a certain schizophrenia, criticizing lower courts for the implementation of the Court's own decisions. The Court accepted the proposition that there was de jure segregation in the Detroit public schools. In so doing, it largely followed the definition of intentional discrimination propounded in Keyes. The Court affirmed the following findings:

The District Court found that the Detroit Board of Education created and maintained optional attendance zones within Detroit neighborhoods undergoing racial transition and between high school attendance areas of opposite predominant racial compositions. These zones, the court found, had the "natural, probable, foreseeable and actual effect" of allowing White pupils to escape identifiably Negro schools. . . . Similarly, the District Court found that Detroit school attendance zones had been drawn along north-south boundary lines despite the Detroit Board's awareness that drawing boundary lines in an east-west direction would result in significantly greater desegregation. ${ }^{165}$

Failing to correct actions that hindered the possibility of integration or to take actions that increased integration, then, constituted de jure discrimination.

tion of the NAACP on school segregation had been rejected by the Court in a signed opinion. The cracks in the wall of unanimity first appeared a year after Swann. Wright v. Council of the City of Emporia, 407 U.S. 451 (1972) (Burger, C.J., Blackmun, Powell, and Rehnquist, J.J., dissenting) and United States v. Scotland Neck City Bd. of Educ., 407 U.S. 484 (1972) (Burger, C.J., Blackmun, Powell, and Rehnquist. J.J., concurring only in the result). The crack widened to a sizable fissure in Keyes, and the unanimous front ruptured completely with Milliken-Chief Justice Burger writing for a majority of five; Justice Stewart filing a separate concurring opinion; Justice White, joined by Justices Douglas, Brennan, and Marshall, dissenting; Marshall writing another dissent, joined by the other three dissenters; and Douglas filing a separate dissent. Levin \& Moise, supra note 27 , at 50,55.

163. Griffin v. County School Bd., 377 U.S. 218, 234 (1964) (Harlan and Clark, J.J., concurring).

164. 413 U.S. at $221(1973)$

165. Milliken v. Bradley, 418 U.S. 717, 725 (1974). [Citations omitted.] 
Other examples included the location of schools within overwhelmingly white or black neighborhoods and some busing of blacks past white schools. ${ }^{166}$

The Court declined, however, to adopt this broad definition of intentional segregation when it considered whether the state or the surrounding school districts had engaged in deliberately segregative practices. If Keyes and that part of the Milliken opinion dealing with the actions of the Detroit school authorities mean that relatively isolated acts of discrimination accompanied by a failure to take actions which would have alleviated segregation suffice to require a racial balance remedy, the Court ignored this proposition when it came to the actions of both the surrounding school districts and the state of Michigan. ${ }^{167}$

"[A]ssum[ing], arguendo, . . . that state agencies did participate in the maintenance of the [segregated] Detroit system . . .,"168 nevertheless, a metropolitan remedy did not flow from the alleged violations. The legislature's repeal of the voluntary desegregation plan adopted by the Detroit Board in 1970 was said to affect only twelve of the twenty-one Detroit high schools and had no causal relation to the distribution of students by race between Detroit and other school districts in the metropolitan area. ${ }^{169}$ The general supervisory powers of the state over local school districts, including supervision of building policies, bonded indebtedness, state financial aid, and other matters, were not deemed sufficient to make the state responsible for the segregation that existed between Detroit and the surrounding suburban districts. ${ }^{170}$ Specific acts of gerrymandering of district lines to achieve racial separation were required for a finding of de jure segregation necessitating metropolitan relief. ${ }^{171}$ Maintenance of existing lines, with the knowledge of the interdistrict racial consequences, was not itself a constitutional violation.

With regard to the appropriate remedy, the Court did not question the Swann-Keyes racial balance approach within Detroit itself. Yet, it introduced a new element with regard to the metropolitan relief requested by the plaintiffs. The Court held that " $t]$ he controlling principle consistently expounded in our holdings is that the scope of the remedy is determined by the nature and extent of the constitutional violation." ${ }^{172}$ The Court expounded this principle in Swann ${ }^{173}$ and Keyes, but certainly did not abide by it in those cases. ${ }^{174}$ No

166. Id. at $725-26$.

167. Id at 745-46.

168. Id. at 746 .

169. Id at 750 .

170. Id. at 751 .

171. Id. at 746-47.

172. Id at 744 .

173. 402 U.S. at 16.

174. In Swann, the statement was articulated to support the breadth of the district court's equitable powers to remedy past wrongs rather than to circumscribe those powers. 402 U.S. at $15,16$. 
serious attempt was made in the earlier opinions to quantify the incremental segregation caused by past acts of discrimination and to tailor the remedy only to that increment. Busing for racial balance was then the order of the day, and this was accomplished by an expansive definition of intentional discrimination and by presuming that the discrimination had a substantial impact beyond the particular schools where discriminatory acts were proven. In Milliken, however, the Court required the following:

Specifically, it must be shown that racially discriminatory acts of the state or local school districts, or of a single school district have been a substantial cause of interdistrict segregation.

[T]he remedy is necessarily designed, as all remedies are, to restore the victims of discriminatory conduct to the position they would have occupied in the absence of such conduct. Disparate treatment of white and Negro students occurred within the Detroit school system, and not elsewhere, and on this record the remedy must be limited to that system. [Citing Swann.] ${ }^{175}$

Amazingly, the majority in Milliken chastised the lower courts for doing exactly what the Court itself had presaged in its decisions in Swann and Keyes. It accused those courts of assuming that only a racially balanced school was a desegregated school. ${ }^{176}$ It relied upon the language of Swann, rather than the actual order in Swann, for the proposition that desegregation "does not require any particular racial balance in each 'school, grade or classroom." "177 It treated the existence of segregation in a school system as only a signal that further inquiry into the causes of that segregation might be necessary. ${ }^{178}$ The point, however, is that the nature of the alleged violations in Milliken did not differ inordinately from Keyes. The connection between constitutional wrong and remedy was just as speculative and inconclusive in the two cases. No new social science research results intruded to justify different results: the Court simply decided to concern itself with missing causal links that had not given it pause in earlier decisions. In so doing, it emphasized instrumental and not interpretive judgments.

In my view, what had begun to change was the underlying principle the Court was applying in segregation cases. In Swann and Keyes, the Court had emphasized the likelihood that the political processes would be corrupted by racial prejudice ${ }^{179}$ and had sought to guarantee an integrated education to as

175. Id. at 745-46.

176. Id. at 740 .

177. Id. at $740-41$.

178. Id. at $741, \mathrm{n} .19$.

179. Swann, 402 U.S. at 13-14 (discussing the "deliberate resistance" to the post-1955 mandates of the Court and the "dilatory tactics of many school authorities"); Keyes, 413 U.S. at 202-03 (quoting Swann regarding the use of decisions about school location and capacity "as a potent weapon for creating or maintaining a state-segregated school system" and the building of new schools "to maintain the separation of the races"). 
many black children as possible by distorting the nondiscrimination principle. Followed to its logical conclusion, the remedy of systemwide integration required in Swann and Keyes should have dictated a similar remedy in Milliken, since there simply were not enough white students in Detroit alone to provide a racially integrated experience for the masses of black children in that school system. In Milliken, however, the Court focused on the nondiscrimination language of earlier opinions and refused to uphold the order for a metropolitan area remedy. ${ }^{\mathbf{1 8 0}}$ In so doing, the Court, in effect, retreated from the Keyes presumptions and required specific proof of intentionally discriminatory acts and of an actual nexus between those acts and any proposed remedy. ${ }^{181}$

The reasoning of Milliken invited social scientists to produce empirical studies on the etiology of school segregation, either to affirm or disaffirm the majority's view of the evidence on causation. And many seized the opportunity -with inconclusive results. ${ }^{182}$ But this invitation itself is something of a canard, for implicit in the Milliken holding is the notion that racial balance as a remedy is dependent on whether intentional acts of discrimination can be tied to some particular increment of school segregation. Rather, the true operative principles are, I suspect, a function of the Court's interpretive judgments about racial prejudice in the decisional process and the desirability of integration. Social science evidence will not carry the day one way or the other.

Developments since Milliken reinforce the view that the Court is moving away from the racial balance remedy and toward the nondiscrimination principle. In Austin Independent School District $v$. United States, ${ }^{183}$ the Court of Appeals for the Fifth Circuit had ordered the adoption of an integration plan that would have achieved a degree of racial balance in every school in the district. Following Keyes and disregarding those aspects of Milliken inconsistent with it, the circuit court relied in part upon the fact that a neighborhood student assignment plan in a school district with segregated neighborhoods would inevitably lead to segregated schools:

[S]chool authorities may not constitutionally use a neighborhood assignment policy that creates segregated schools in a district with ethnically segregated residential patterns. A segregated school system is the foreseeable and inevitable result of such an assignment policy. When this policy is used, we may infer that the school authorities have acted with segregative intent. ${ }^{184}$

180. But see Buchanan v. Evans, 555 F.2d 373, cert. denied sub nom. Delaware St. Bd. of Educ. v. Evans, 434 U.S, 880 (1977).

181. See Dayton Bd. of Educ. v. Brinkman, 433 U.S. 406 (1977).

182. See generally G. Orfield, supra note 13; Farley, supra note 108, at 164; Pettigrew, $A$ Sociological View of the Post-Bradley Era, 21 Wayne L. Rev. 813 (1975); Taeuber, Demographic Perspectives on Housing and School Segregation, 21 WAyne L. REv. 833 (1975); Wolf, Northern School Desegregation and Residential Choice, supra note 14, at 63.

183. 429 U.S. 990 (1977).

184. United States v. Texas Educ. Agency, 532 F.2d 380, 392 (5th Cir. 1976), vacated and remanded mem. sub nom. Austin Indep. School Dist. v. U.S. 429 U.S. 990 (1977). 
The circuit court was too explicit in its adoption of integrationist principles. It is one thing to order integration under the guise of the nondiscrimination principle, and quite another to admit that the necessary predicate for integration is board policy corrupted by racial prejudice or that integration itself is the goal. The Supreme Court, over the dissents of Justices Brennan and Marshall, vacated the judgment of the Court of Appeals and remanded the case for reconsideration ${ }^{185}$ in the light of Washington $v$. Davis, ${ }^{186}$ a leading employment discrimination case holding that underrepresentation of blacks, standing alone, does not constitute proof of racial discrimination.

The Court's cryptic, one sentence order in Austin does not appear to merit much consideration. The decision to vacate and remand often smooths over inconsistent and conflicting rationales for the result. ${ }^{187}$ Justice Powell, joined by Chief Justice Burger and Justice Rehnquist, recognizing the ambiguity of the majority's handiwork, made it abundantly clear, in a concurring opinion, where they at least stood: "[T]he plan is designed to achieve some predetermined racial and ethnic balance in the schools rather than to remedy the constitutional violations committed by the school authorities."188 The three justices doubted that the Austin school system would ever have achieved the degree of integration called for by the plan, even if there had been no constitutional violation, since in the causal language of Milliken the primary reasons for segregation were not attributable to school authorities:

The principal cause of racial and ethnic imbalance in urban public schools across the country-North and South-is the imbalance in residential patterns. Such residential patterns are typically beyond the control of school authorities. For example, discrimination in housing-whether public or private - cannot be attributed to school authorities. Economic pressures and voluntary preferences are the primary determinants of residential patterns. ${ }^{189}$

Significantly, Powell attributes no importance to the fact that the school board adopted a neighborhood assignment plan knowing that it would lead to segregated schools. The "knowing" standard of Keyes is rejected in favor of the "intentional" discrimination standard of Milliken. Furthermore, not only must the remedy be reasonably commensurate with the wrong, but lower courts must also attempt to determine what the racial composition of the

185. 429 U.S. 990 (1977). On remand, the Fifth Circuit again ordered a racial balance remedy, finding the necessary causal links. United States v. Texas Educ. Agency, 564 F.2d 162 (5th Cir. 1977), motion for rehearing en banc denied, 579 F.2d 910 (5th Cir. 1978).

186. Washington v. Davis, 426 U.S. 229 (1976).

187. Some of the justices may have wished to adhere to a racial balance remedy but were simply unprepared to move beyond the justifications proffered in Keyes and Swann, believing that they could not command a majority of the Court or that it was a politically awkward time to clarify the law in this fashion. Other justices may have desired to re-establish nondiscrimination, with a remedy limited to the scope of the wrong as the governing principle.

188. 429 U.S. 990, 993 n.3 (1977) (Powell, J., concurring).

189. Id. at 994 (footnotes omitted). 
schools would have been-hypothetically-had there been no unconstitutional discrimination. This formula is applied for the first time to a city which at one time did have an official policy of separating the races in the public schools. This is patently inconsistent with Swann. The concurring opinion also mentions the possibility of busing as a means of "implementing desegregation," but suggests that such busing would be rare if the appropriate remedial limitations are observed and the "tender age" of those attending elementary schools is taken into account. ${ }^{190}$ Powell does not overtly say that nondiscrimination, and not integration, is the exclusive remedy for discrimination, but he comes quite close to that conclusion. Finally, Powell does not rely upon any social science evidence, nor does he cite to the record of the case to support his assertions.

Dayton Board of Education v. Brinkman, ${ }^{191}$ the premier desegregation case of the 1976 Supreme Court term, perhaps demonstrates more than any other case the limits of the current consensus among the justices on the appropriate principles for deciding the school desegregation cases. Although only three of the justices had explicitly opted for a limited remedial approach in the Austin decision, Brinkman was decided by a unanimous court. (Justice Marshall did not participate.) The balance of power on the desegregation question apparently now rests with Justices Stevens, Blackmun, White, and Stewart. Justice Rehnquist, an advocate of the basic nondiscrimination formula, wrote an opinion that managed to attract the votes of all the participating justices. ${ }^{192}$ Given the differences among the justices articulated in Keyes, Milliken, and Austin, Justice Rehnquist's ability to muster a unanimous Court is something of a tour de force. As is so often the case, however, such miracles are often a function of a patchwork of unintelligibility.

In Brinkman, the district court found only isolated instances of intentional discrimination by the Dayton school authorities. These consisted of some faculty segregation, the establishment of an all black central high school, and some evidence that a few of many optional attendance zones had the effect of increasing segregation in high schools. Beyond this, the facts were remarkably similar to Keyes. The district court found that the majority of Dayton schools were racially imbalanced, that neighborhoods were segregated in Dayton, and that the school board had failed to take affirmative action to alter attendance zones or otherwise act to alleviate the segregation. Further, a previous board

190. Id. at 994-95. The Court had suggested in Swann that a busing remedy may be limited "when the time or distance of travel is so great as to either risk the health of the children or significantly impinge on the educational process." 402 U.S. at 30-31

191. Dayton Bd. of Educ. v. Brinkman, 433 U.S. 406 (1977).

192. There were only brief concurring opinions by Justices Stevens and Brennan. 433 U.S. at 421-24 (1977). Justice Brennan, together with Justice Marshall, had dissented in the Austin case. 420 U.S. at $990-91$ (1977). 
of education had adopted resolutions "stating that it recognized its own fault in not taking affirmative action" to reduce segregation in Dayton. ${ }^{193}$ This resolution was repudiated by a subsequent board. The district court then concluded that the "'racially imbalanced schools, optional attendance zones, and recent Board action . . . are cumulatively in violation of the Equal Protection Clause." "194 The judge ordered the elimination of optional attendance zones, the selection of new students for the high schools by a random process, and the racial balancing of classified personnel in each of the system's schools. Unlike the district court order in Keyes, the order in Brinkman did not require systemwide reassignment of students.

After a series of reversals by the Court of Appeals for the Sixth Circuit, ${ }^{195}$ culminating in a 1976 direction to "adopt a system-wide plan for the 19761977 school year," ${ }^{96}$ the district court finally entered a systemwide racial balance remedy requiring:

that the racial distribution of each school in the district be brought within $15 \%$ of the $48 \%-52 \%$ black-white population ratio of Dayton. As finally formulated, the plan employed a variety of desegregation techniques, including the "pairing" of schools, the redefinition of attendance zones, and a variety of centralized programs and "magnet-schools."197

The Supreme Court unanimously vacated and remanded the decision of the appellate court affirming the district court's plan. Read most narrowly, the opinion is addressed only to the issue of the proper role of appellate courts in reviewing decisions of federal district courts: the court of appeals erred in reversing the district court's original determination of the appropriate remedy without specifically declaring that the lower court had made erroneous findings of fact or had reached improper legal conclusions:

On appeal, the task of a court of appeals is defined with relative clarity; it is confined by law and precedent, just as are those of the district courts and of this Court. If it concludes that the findings of the district court are clearly erroneous, it may reverse them under Fed. Rule Civ. Proc. 52(a). If it decides that the district court has misapprehended the law, it may accept that court's findings of fact but reverse its judgment because of legal errors. Here, however, as we conceive the situation, the court of appeals did neither. It was vaguely dissatisfied with the limited character of the remedy which the district court had afforded plaintiffs, and proceeded to institute a far more sweeping

193. 433 U.S. at 414 .

194. Id. at 413 .

195. Brinkman v. Gilligan, 503 F.2d 684 (6th Cir. 1974) (affirming and remanding); 518 F.2d 853 (6th Cir. 1975) (remanding with directions). The District Court's original decision was delivered on February 7, 1973, before the Supreme Court's decision in Keyes, and its Supplemental Opinion on Remedy was rendered on July 13, 1973, shortly after Keyes was decided. Civil No. 72-137 (D. Ohio, 1973).

196. 518 F.2d at 857 .

197. Dayton Bd. of Educ. v. Brinkman, 433 U.S. at 408-09 (1977). 
one of its own, without in any way upsetting the district court's findings of fact or reversing its conclusions of law. ${ }^{198}$

This mode of analysis is extremely misleading, although no more misleading than past discussions of the equitable remedial powers of trial courts. ${ }^{199}$ Once again the Court has sought refuge in notions of process, trying to paper over fundamental divisions on appropriate equal protection principles. On a record virtually indistinguishable from Keyes, the Brinkman trial judge had declined to mandate racial dispersion as the necessary remedy, refusing to do precisely what the Supreme Court had ordered in Swann and Keyes. The court of appeals was saying, in effect, that the lower court had reached the wrong legal conclusion.

The Supreme Court, adhering to the principles recently enunciated in Milliken, questioned whether a systemwide remedy was commensurate with the alleged constitutional violations. In its view, resolution of this issue would require new findings with regard to other possible violations apparently not in the record, suggesting that the trial court, if necessary, could and perhaps should hold hearings to supplement the record. The net result was to invite the district court to make additional factual findings to support its sweeping remedy. By hiding behind this procedural facade, the justices may have insured that virtually indistinguishable forms of school segregation would result in different remedies at the discretion of trial judges, but they avoided having to choose between competing principles of racial justice.

Beyond the narrow holding of Brinkman, the case is filled with dicta indicating a shift toward a more limited remedial standard. Whether the "swing" justices are in agreement with the dicta is not clear, since only two of them wrote concurring opinions. Justice Rehnquist, for the Court, stressed the isolated nature of the instances of intentional discrimination. ${ }^{200}$ Clearly, the mere existence of racial isolation cannot justify a systemwide racial balance remedy:

[T] he Court of Appeals simply had no warrant in our cases for imposing the systemwide remedy which it apparently did. There had been no showing that such a remedy was necessary to "eliminate all vestiges of the state-imposed school segregation." It is clear from the findings of the District Court that Dayton is a racially mixed community, and that many of its schools are predominantly white or predominantly black. This fact without more, of course, does not offend the Constitution. ${ }^{201}$

Rehnquist accused the court of appeals of applying a "sort of 'fruit of the poisonous tree" "doctrine, only speculatively tying the three segregative acts

198. 433 U.S. at $417-18$ (1977).

199. See, e.g. Swann v. Charlotte-Mecklenburg, 402 U.S. 1, 15 (1971); Davis v. Board of School Comm'rs, 402 U.S. 33, 37 (1971).

200. Dayton Bd. of Educ. v. Brinkman, 433 U.S. 406, 413 (1977).

201. Id. at 417 . 
found by the district court to the broad racial imbalance that exists in the Dayton schools. ${ }^{202}$ Yet such apparently tenuous connections were accepted by the Court in Keyes and Swann. ${ }^{203}$ If a majority of the justices agreed with the Brinkman dicta, Keyes and Swann have been effectively overruled. ${ }^{204}$

Justice Stevens, in his concurring opinion, simply notes that a finding of intentional discrimination is a function of the "objective evidence concerning the effect of the Board's action" and not of some subjective evaluation of the motives of the members of the school board, ${ }^{205}$ presumably meaning that superficially neutral student assignment criteria may be tainted by racial prejudice. Thus Stevens might give some weight, as did the Keyes majority, to the board's having adopted a neighborhood schools policy with the knowledge that this would inevitably lead to substantial school segregation. Whether this alone would be a sufficient predicate for a system-wide racial balance remedy is unclear-particularly if a neighborhood schools policy would have been the preferred policy regardless of racial prejudice. ${ }^{206}$

Although Justice Brennan agrees with the majority that the "violations found by the District Court were not sufficient to justify the remedy imposed," 207 he emphasizes that the case "turns upon the "proper allocation of functions between the district courts and the courts of appeals within the federal judicial system.' "208 Citing Keyes, he notes that "a finding of intentional segregation as to a portion of a school system is not devoid of probative value in assessing the school authorities' intent with respect to other parts of the same school system." ${ }^{209}$

The overall impression is that the justices were unable to agree on a majority opinion on the merits, and that Brinkman is still one more case in a long line of cases that can be made to stand for whatever principle the Court wishes it to in the future.

\section{$\mathrm{V}$ \\ Milliken II: Bringing Chaos out of Confusion}

The picture that emerges is of a Court, deeply divided, adhering to a flawed remedial philosophy capable of yielding diverse results. A majority

202. Id.

203. But see Taylor, supra note 136 , at 37 .

204. This reading, however, is further complicated by the fact that the Court allowed the existing racial balance remedy to remain in effect pending further hearings and orders by the District Court upon remand of the case. Dayton Bd. of Educ. v. Brinkman, 433 U.S. 406, 421 (1977).

205. Id.

206. See text, supra at 78-79.

207. Dayton Bd. of Educ. v. Brinkman, 433 U.S. at 421 (1977) (Brennan, J., concurring).

208. Id. at 422 .

209. Id. at 423, citing Keyes v. School Dist. No. 1, 413 U.S. 189, 207 (1973). 
seem on the verge of repudiating the process corruption and group protection tendencies of Swann and Keyes, yet are apparently unwilling to embrace the nondiscrimination remedy endorsed by three of the justices in Austin. ${ }^{210}$ In all of this, social science research has played a quite limited role. In the post-Brown era the Court generally eschewed reliance on social science findings, even in the Swann case where substantial empirical evidence with respect to white flight and optimal racial balances in public schools had been introduced at the trial level. ${ }^{211}$ If the remedial theory is based on instrumental assumptions, ${ }^{212}$ the failure to rely on social science research reinforces the belief that the Court is still groping for solutions. Milliken $I I,{ }^{213}$ however, is something of an exception. In many ways, certainly from the perspective of the social scientist, the unanimous opinion is quite remarkable.

After the Supreme Court's decision in Milliken $I$ and its remand to the lower courts, Judge DeMascio, the new trial judge, ordered the parties, including the Detroit School Board, to submit desegregation plans geographically limited to the Detroit school system. ${ }^{214}$ The Supreme Court addressed itself only to those aspects of the plan requiring the implementation of remedial or compensatory education programs and affirmed the lower court's order.

The "educational components" of the desegregation plan were of tremendous breadth, and the cost was to be borne equally by the Detroit school board (an enthusiastic advocate of the plan rather than a reluctant defendant) and the State of Michigan (a somewhat less enthusiastic defendant). ${ }^{215}$ The State was ordered to pay about $\$ 5.8$ million to the Detroit school district as its pro rata share. ${ }^{216}$ Among the compensatory elements of the plan were the following:

1. A remedial reading and communications skills program designed " $[t] o$

210. Notes 183-90 supra and accompanying text.

211. See generally Equal Educational Opportunity, supra note 7, at 452.

212. Notes 102-11 supra and accompanying text.

213. Milliken v. Bradley, 433 U.S. 276 (1977).

214. The Board's plan called for the busing of 51,000 students, and "contemplated achieving a $40 \%-60 \%$ representation of Negro students in the identifiably white schools, while leaving untouched in terms of pupil reassignment schools in three of the Detroit system's eight regions." 433 U.S. at 272, n.4. Located in the central city, the latter three areas had an overwhelmingly black student population. Judge DeMascio rejected that part of the Board's reassignment plan that relied upon "an impermissible use of 'arbitrary' racial quotas," but approved a more limited reassignment plan apparently sufficient "to eliminate "racially identifiable white elementary schools,' while ensuring that 'every child will spend at least a portion of his education in either a neighborhood elementary school or a neighborhood junior and senior high school.'" Id. The court of appeals disapproved of the omission of the three regions, and remanded the case for further consideration. 540 F.2d 229, 238, 247 (6th Cir. 1976). These proceedings were still pending at the time of the Supreme Court decision in Milliken v. Bradley, 433 U.S. 267 (1977).

215. 433 U.S. at 279 .

216. Id. at 295 . 
eradicate the effects of past discrimination. . . Program formulation and implementation were left to the Superintendent and to a committee appointed by him. ${ }^{217}$

2. A comprehensive in-service training program designed to provide special training for professional and instructional personnel to ease the problems associated with the desegregation process. ${ }^{218}$

3. A testing program designed to insure that discriminatory testing procedures were not employed in the district and that the test would be "administered in a way 'free from racial, ethnic and cultural bias.' "219

4. A counseling and career guidance program "to counsel students concerning the new vocational and technical school programs available under the [desegregation plan]. . ."220

These were the items that the state contested. The state had acquiesced in judicial orders to "create five vocational education centers devoted to in-depth occupational preparation in the construction trades, transportation and health services;" to establish two new technical high schools emphasizing business curriculum; to create a new vocational education curriculum, including an additional grade thirteen; to include multi-ethnic studies in the curriculum; to promulgate a "Uniform Code of Conduct;" to plan for "co-curricular activities" with artistic and educational institutions; and to establish a "community relations program" outlined in some detail in the district court order. ${ }^{221}$

Perhaps the real reason the state agreed to so many of the items on this remarkable laundry list of educational components is that the Detroit school system was in utter disarray. Justice Powell, in a grumbling but pragmatic concurring opinion, noted that "the District Court virtually assumed the role of school superintendent and school board." 222 Consider the situation faced by the District Court:

It found the structure of the Detroit school system "chaotic and incapable of effective administration." . . The "general superintendent has little direct authority." . . Each of the eight regional boards may be preoccupied with "distribut[ing] local board patronage." ... The "local boards have diverted resources that would otherwise have been available for educational purposes to build new offices and other facilities to house this administrative overload." “. . Rather than devoting themselves to the educational system and the desegregative process, board members are busily engaged in politics not only to assure their own re-election but also to defeat others with whom they disagree." ... . [T] he court also noted-discouragingly-that the election then

217. Id. at 275

218. Id. at $275-76$.

219. Id. at 276 .

220. Id.

221. Id. at 294, n.2 (Powell, J., concurring).

222. Id. at 297 (Powell, J., concurring). 
approaching "may well [result in] a board of education consisting of members possessing no experience in education."223

Under such circumstances, the Detroit School Board not only acquiesced in the virtual takeover by the federal courts, but also agreed to the "equalization of all school facilities and buildings preparatory to the 1976-77 school term" and to the continuation of a comprehensive renovation and construction program. ${ }^{24}$ The School Board apparently exchanged its autonomy for the opportunity to raid the state treasury under the authority of a federal district court.

Milliken II may well stand for the time-honored proposition that exigency creates its own rules of constitutional decisionmaking. ${ }^{225}$ What is surrealistic about Milliken II, however, is that it emanates from a Court, many of whose justices have strongly endorsed the proposition "that the scope of the remedy is determined by the nature and extent of the constitutional violation." 226 Without a dissenting vote, the very notions of federalism and local control raised to such heights in Milliken I and San Antonio Independent School District $v$. Rodriguez ${ }^{227}$ somehow have been left by the wayside.

Milliken $I I$ and the other post-Keyes decisions are difficult to square. In the litigation that led to Milliken I, the State of Michigan was not clearly found to have committed intentional acts of discrimination. The Court simply held that, even assuming that the allegations of improper conduct were true, they were not sufficient to trigger a metropolitan remedy. ${ }^{228}$ Discussion of the state's alleged constitutional wrongs was relegated in Milliken II to a footnote, ${ }^{229}$ in which it was noted that in 1973 the court of appeals had made findings with regard to the state's unconstitutional conduct that were unchallenged in Milliken I-a technically accurate but misleading statement.

The two most serious violations found by the district court were as follows: " " $t]$ he State and its agencies . . . acted directly to control and maintain the pattern of segregation in the Detroit schools;" and "the Michigan legislature enacted a law forbidding the carrying out" of the Detroit school board

223. Id. at 296-97 [Citations omitted].

224. Id. at 297, n.3 (Powell. J., concurring).

225. But see Home Bldg. \& Loan Ass'n v. Blaisdell, 290 U.S. 398, 425-26 (1934) (Hughes, C.J.).

226. Milliken v. Bradley, 418 U.S. 717,744 (1974). Justice Powell, who not only doubts that the findings were specific enough to meet the standards of Brinkman, but who also doubts "whether there is any precedent for a federal court's exercising such extensive control over the purely educational responsibilities of a school board," 433 U.S. at $294 \mathrm{n} .2$ (Powell, J., concurring), accepted the result.

227. 411 U.S. 1 (1973).

228. The state's alleged violations were confined to the segregation within the Detroit School District. There was no evidence that the State had undertaken any activity leading to segregation between Detroit and the outlying districts. Milliken v. Bradley, 418 U.S. at 748 (1974).

229. 433 U.S. at $267-70$, n.l. 
desegregation resolutions. ${ }^{230}$ The first finding appears inconsistent with the notion that knowledge that an act will have a disproportionate racial effect, without proof that the act was motivated by racial prejudice, is not enough to make a claim of intentional segregation. Moreover, if supervisory control of local school districts and their boundaries is sufficient to implicate the state-that is, the state failed to act to counter the segregative acts of local entities-then why was this not sufficient to trigger metropolitan relief in Milliken $I$ ? This is particularly remarkable in view of the findings of intentional discrimination: "[I]mproper use of optional attendance zones, racially based transportation of schoolchildren, improper creation and alteration of attendance zones, grade structures, and feeder school patterns. . ."231 Since some of these elements were also present in Brinkman, Milliken II might be construed as a return to the corruption theory on which Keyes and Green may be grounded.

Milliken II's remedial approach is even more problematic in the light of the recent desegregation cases. In Keyes and Swann the Court, without the aid of any research findings, found that the speculative relationship between present patterns of neighborhood (and hence school) segregation and past discriminatory acts by the school board was sufficient to thrust the virtually impossible burden of justification on the school board. Those cases held that the appropriate remedy for the effects of past discrimination was racially balancing the schools. But almost every case since Keyes has, however unclearly, evidenced an erosion of these tenets. In Milliken $I,{ }^{232}$ Pasadena, ${ }^{233}$ Austin, ${ }^{234}$ and Brinkman, ${ }^{235}$ many of the justices, unpersuaded that the needed causal links could be forged, indicated that remedies must be severely limited to be commensurate with the harm. Yet the Court relied on such causal relationships in Milliken II. Given the debate in the social science community about the effectiveness of such remedial measures as special reading programs, in-service training for teachers, and efforts to eliminate testing and counselling bias, why should these measures be any more efficacious than racial integration in improving the plight of minority children injured by past segregation? ${ }^{236}$ The connections are speculative for all of these remedies. In-

230. Id.

231. Id

232. Milliken v. Bradley, 418 U.S. 717 (1974).

233. Pasadena City Bd. of Educ. v. Spangler, 427 U.S. 424 (1976).

234. Austin Ind. School Dist. v. United States, 429 U.S. 990 (1976)

235. Dayton Bd. of Educ. v. Brinkman, 433 U.S. 406 (1977).

236. See generally Coleman Report, supra note 27; R.L. Crain, 2 Southern Schools: An Evaluation of the Effects of the Emergency School Assistance Program and of School Desegregation (National Opinion Research Center report, 1973); C. Jencks, supra note 27; ON Equality of Educational Opportunity, supra note 110; R. Rist, The Invisible Childoren: School. Integration in American Society (1977); Bowles \& Levin, The Determinants of Scholastic 
deed, many eminent social scientists have argued that an integrated education is more likely to produce benefits than are additional expenditures of money. ${ }^{237}$

Milliken II suggests that where the remedies sought by the plaintiffs do not include integration (busing), the Court may be quite receptive, irrespective of how attenuated the remedies are in relation to the original wrongs. The concept of "benefit" to minorities may also be undergoing change. That is, the high probability of racial prejudice or the need to protect blacks as a group does not inevitably require an integration remedy; rather the insult and stigma may be reduced and the plight of blacks improved without resort to compulsory mixing of the races. Whether such measures are efficacious remains to be seen. Moreover, the Court may perceive that there is greater public acceptance for busing state dollars rather than white children, as evidenced by the significant progress that has been made in school finance reform $^{238}$ despite the constitutional setback in Rodriguez. ${ }^{239}$ Whether this perception is correct is difficult to evaluate. The outcries over high property taxes, over the inability of the schools to teach the "fundamentals," and over the lack of accountability of educators to the public may argue for a contrary conclusion.

Finally, Milliken II lends support to my view that social science research has not played a very great part in school desegregation litigation. In Brown it was politically expedient to bolster the Court's opinion by citing a highly inadequate social science literature. Subsequently, perhaps because social science findings did not support many of its conclusions, the Court found it convenient to ignore the social scientists. In Rodriguez the Court referred to the lack of agreement in social science studies, based on surveys such as the Coleman Report, to support its view that the federal courts should not interfere with inequitable state school finance schemes. ${ }^{240}$ In Milliken $I I$, the Court seemed to attach great significance to the testimony of "expert witnesses" on the necessity for remedial programs in desegregating school districts. ${ }^{241}$ Yet that testimony was anecdotal and highly subjective and could easily have been countered by the testimony of still other experts. Indeed, the Michigan State

\footnotetext{
Achievement-An Appraisal of Some Recent Evidence, 3 J. Human Resources 3 (1968); Social Science and Social Policy, supra note 71 ; Levin, supra note 70; Equal Educational Opportunity, supra note 7.

237. See, e.g., C. JENCKS, supra note 27, at 93-109 (desegregation will reduce slightly the overall amount of variation in test scores; additional school expenditures are unlikely to increase achievement test scores).

238. See Education Comm'n of the States, School Finance Reform in the States: 1978, at vii-x, 1-9, 45-53 (1978).

239. San Antonio Indep. School Dist. v. Rodriguez, 411 U.S. 1 (1973).

240. $I d$. at 43,46, n.101.

241. 433 U.S. at 273-74.
} 
Board of Education submitted into evidence a critique of the Detroit school desegregation plan in which it asserted that although "[i]t is possible that none of the thirteen 'quality education' components is essential . . . to correct the constitutional violation, eight of the thirteen proposed programs nonetheless deserved special consideration in the desegregation setting." 242 Perhaps the Court was deferring to the educational expertise of Detroit school administrators, and not treating their testimony as a presentation of social science research results. Social policy research appears to be employed by the Court as "political ammunition" when it supports results already reached on other grounds. ${ }^{243}$ This does not suggest that such research is not worth doing: it only suggests its limited influence on the articulation of the Supreme Court's desegregation policy.

\section{VI \\ A Perspective on Social Science Research, Reasoned Elaboration and the Segregation Dilemma}

The reasons that social science research has not generally been decisive in the school desegregation cases are many. When the constitutional right to be free of racial prejudice in government decisions is articulated in instrumental terms, the social scientist must ask what the world would have been like without such discrimination. And what is the injury to blacks and how may it be alleviated? These questions are intelligible to social scientists, but the nature of the inquiry, given the current state of social science methodologies, renders the answers elusive. Complexity and the absence of a dominant scientific paradigm are decisive. And the inability to provide unambiguous answers reinforces the tendency on the part of judges to make desegregation questions turn on interpretive judgments-judgments as to the probability that the political process is corrupted by racial prejudice and judgments about the wisdom of pursuing integration in its own right. There may be a nod in the direction of policy research. But this is not the nod of acquiescence. Rather, it is a response to the crisis of legitimacy in law and reflects the perceived need to justify decisions with whatever is at hand. As an ad hoc response, the same policy research will be disregarded on another occasion.

The message for social scientists is clear. Acquiring knowledge for its own sake should continue, but not on the assumption that courts will translate research results into judicial decisions. Perhaps such research will tell us much about combatting racial isolation in the public schools: certainly it can identify

242. Id. at 273 .

243. See Social Science and Social Policy, supra note 71, at 90. 
costs that lawyers and judges may well overlook. And such costs may not be without normative significance:

[W] hen we try to apply social science to achieve certain ends we clearly must be concerned with values . . . . for some people may find means morally unacceptable that might be practically successful. The difficult question is what general ends mankind or a government ought to pursue. Doctrine holds that this question cannot be answered by evidence. I am not wholly sure that it cannot, at least in the extreme case. Though evidence may indicate that the attainment of a certain end will be very costly, we may still be willing to pay the price. But if evidence showed that it would be impossible, we should be fools to pursue it. ${ }^{244}$

But until the social science millenium, policy research can best serve by yielding insights as to how to go about the task of bringing school systems into conformity with the law with the least trauma to those affected, and by playing a reporting function, telling us what the results of judicial intervention are. ${ }^{245}$

For the foreseeable future, I predict that the evolution of desegregation will ultimately be primarily a function of interpretive judgments about the political process and the sort of society to which we should aspire. Social scientists, of course, are quite capable of rendering such interpretive judgments, and these may well influence the judicial process. But they should not parade in the garb or language of the empiricism of the physical sciences. As Anthony Giddens is supposed to have remarked, "those who still wait for a Newton' of the social sciences 'are not only waiting for a train that won't arrive, they're in the wrong station altogether.' "246

For judges and lawyers, one lesson of the last twenty-five years of school desegregation litigation is that the social sciences will not be able to provide the answers to those hard questions that seem so intractable when analyzed in the legal framework. If legal realism has eroded the foundations of law and the legal method, the answers will have to come from within. There are no props that can be conveniently borrowed from other disciplines. The difficult normative judgments cannot be avoided. In the desegregation cases, the Supreme Court should proceed with candor and honestly elaborate the reasons for its decisions. Interpretive judgments should not be buried in the language of causation and remedies, thereby inviting a partnership with the social sciences that can never be. The Court must take its chances that reason and history, not a false scientific allure, will vindicate its concepts of racial justice. Perhaps judges should take to heart Peter Winch's admonition to philosophers:

244. Homans, supra note 70, at 530-31.

245. Social Science and Social Policy, supra note 71 , at 79.

246. Skinner. The Flight from Positivism, The N.Y. Review of Books, June 15, 1978, at 26. 
Philosophy ... has no business to be antiscientific: if it tries to be so it will succeed only in making itself look ridiculous. Such attacks are as distasteful and undignified as they are useless and unphilosophical. But equally . . philosophy must be on its guard against the extra-scientific pretensions of science.

....

Whereas the scientist investigates the nature, causes and effects of particular real things and processes, the philosopher is concerned with the nature of reality as such and in general. . . "What is real?" involves the problem of man's relation to reality, which takes us beyond pure science. ${ }^{247}$

247. P. WiNCH, supra note 76 , at 2, 8-9. 